\title{
SECURING UNITY AND REVERENCE: CHINESE ONTOLOGICAL SECURITY ACROSS \\ ITS MARITIME AND FRONTIER DISPUTES
}

BY

\section{HENRY CURTIS}

\author{
A thesis \\ submitted to the Victoria University of Wellington \\ in fulfilment of the requirements for the degree of \\ Master of International Relations
}

Victoria University of Wellington 


\section{Table of Contents}

Abstract

Acknowledgements..........................................................................................................................

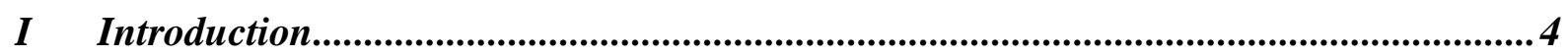

II Theory and Methodology .................................................................................................. 7

III A Brief History of China's Territorial Disputes ................................................... 13

A Nineteenth Century Territorial History ….......................................................... 13

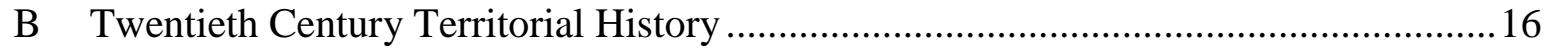

C Disputes of the People's Republic of China: 1949-Present ........................................ 19

IV Literature Review ......................................................................................................29

$V \quad$ Chinese National Identity in its Territorial Disputes ...................................................37

A Chinese National Identity: Exceptionalism, Humiliation and Unity. ...........................37

B The 1950s, Chinese Exceptionalism and National Humiliation ..................................40

C The late 1950s, the 1960s, and the Domestic Mobilisation of Unified China..............43

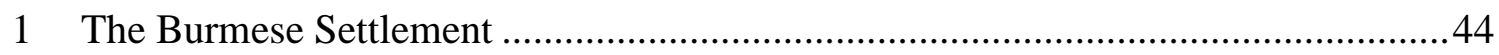

2 India, Tibet, and the Dalai Lama: Concession and Conflict ....................................47

D The 1970s: The Central Kingdom in the South China Sea .........................................50

E The 1980s and 1990s: The Reform Age and the turn in Chinese Exceptionalism ........52

1 The Sino-Indian Dispute and Defining the Chinese Nation.....................................53

2 Cooperation without Settlement in the South China Sea ........................................56

F Continuing and Predicted Trends in Chinese Territory Disputes ...............................58

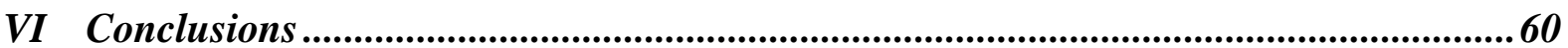

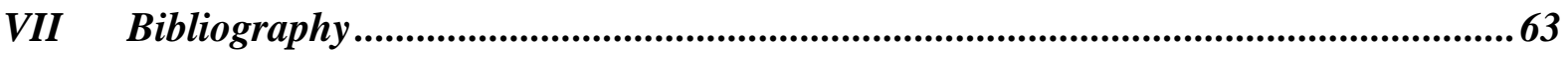




\begin{abstract}
This thesis draws on the Constructivist school of International Relations, applying the theory of ontological security to explain diverging patterns of behaviour by China across its maritime and frontier territorial disputes. Since the establishment of the People's Republic of China, these patterns have seen China consistently interact with states adjacent to its frontiers to settle disputes peacefully, with occasional instances of conflict. Conversely, in its maritime disputes, though varying in its levels of aggression and cooperation, China has resolutely refused to settle with disputant states. In examining these varying behaviours, it is argued that differences derive from the differing ability of China to secure its national identity between the two types of dispute. Analysing the examples of the Sino-Indian dispute and border war, the Burmese border agreement, and the ongoing South China Sea disputes, periods of conflict and settlement in these disputes are compared to changing manifestations of Chinese national identity. What results is an illustration of frontier border settlement contributing to the security of China's identity as a unified, pluralistic nation state. The absence of national minority populations in relation to maritime disputes alternatively sees continued interaction in these disputes as securing China's identity as the superior 'Central Kingdom' relative to peripheral South East Asian states, while offering little incentive for settlement. Both types of dispute can be viewed as contributing to the biographical narrative of China's 'Century of Humiliation'. This thesis presents a significant departure from existing studies of China's disputes, predominantly undertaken from a Realist perspective. Additionally, it expands on existing Constructivist literature by demonstrating how national identity can result in a range of behaviours across a range of differing disputes, further validating the emerging ontological security approach within International Relations scholarship.
\end{abstract}




\section{Acknowledgements}

First and foremost, thanks must be given to Dr Alexander Bukh, whose lessons and supervision have constituted the near entirety of my education in International Relations. In addition, his reviews, comments and encouragement, as well as his introduction of the topic of this thesis, have proved indispensable to its completion. In reviewing, commenting and proofreading this work, I would like to thank Emily Colgan and Joan Curtis for their invaluable efforts. Thank you to the faculty of the Victoria University School of History, Philosophy, Political Science and International Relations for their support throughout my Master of International Relations. For their financial support, and in providing time to complete this degree part-time, thanks is given to the New Zealand Defence Force. Finally, thank you to Richard and Nicola Curtis for their unstinting support. While I could also use this page to thank Mary, Humphrey and Elsie, this would in no way do justice to their patience, love and encouragement for me throughout the last two years; I will simply have to trust that I can show them this appreciation now that they have their evenings with me back. 


\section{Introduction}

Since its establishment in 1949 the People's Republic of China (PRC) has maintained or settled territory disputes across most of its borders. On its frontier, that is the borders shared with its continental neighbours, settlement of disputes has been widespread, though not total. Disputes remain with India, and settlement when it has occurred has been undertaken largely in two distinct periods of time, the early 1960s and the 1990s. Conversely, China has maintained a number of offshore maritime disputes which have shown little likelihood of settlement. Both types of dispute have at times resulted in conflict. A number of questions can be asked of China's disputes. Why, given the preponderance of settlement in frontier disputes have maritime disputes been left almost exclusively unsettled? Why too, have some frontier disputes gone unsettled despite the willingness of China to settle others? And how can we explain the turns to conflict where these have occurred?

The purpose of this research has been to undertake a comparative study of Chinese territorial disputes between China and neighbouring states across both land and maritime borders, with the aim of providing answers to the questions asked above. This research is significant in that it deviates from the usual theoretical approach of International Relations scholars regarding this topic, by approaching the study from a constructivist perspective. To this end, variables in the disputes as they relate to China's changing national identity have comprised the sum of the analysis. While there is a great deal of scholarship which focuses on certain specific disputes China has maintained with its neighbours, much of this analysis is undertaken from a realist perspective. Furthermore, while it is commonplace for scholars to examine China's disputes individually, or to systematically study China's disputes with its continental neighbours, comparisons of China's inland and offshore disputes constitute a significantly under-researched area of international relations.

This thesis argues that China's behaviour in its territory disputes should be viewed as a process of pursuing ontological security, in which actions are taken to reduce threats to, or to enhance, China's self-identity. In examining the varying behaviours noted above, it is argued that differences derive from the differing ability of China to secure its national identity between the two types of dispute. The Chinese ontologies which are examined in this paper are those of Chinese exceptionalism, the Century of Humiliation, and the unified Chinese nation. While these ontologies are interrelated, and indeed allusions to the first two can be 
viewed in all of China's disputes, the securing of China's identity as a unified but pluralistic nation state is only achievable through its frontier disputes, in which national minorities are present along or near disputed borders. Thus, settlement has been common in frontier disputes in periods when the domestic strengthening of the unified nation of China was viewed as important to the state's goals, and conflict has occurred where this identity has come under threat. Alternatively, it is argued that Chinese behaviour in maritime disputes has served to strengthen China's identity relative to other disputant states, and serves to secure China's identification as the centre of the Asian world. This identity has at times been secured through the pursuit of deference from disputant states, or through China acting as the moralistic leader of those states.

This thesis is not exhaustive on the topic of China's many territory disputes. Instead, case studies have been selected in order to illustrate the author's argument. The inland disputes of China's borders with India and Burma will be assessed, with analysis of China's ontological relationship with the associated borderland people being the focus of the argument. These two disputes reveal varying aspects of China's approach to territory disputes. Both of these disputes arose from similar imperial legacies in the nineteenth century, and at times their origins overlap. However, while the Burmese dispute was settled successfully and early in the PRC's history, the Indian dispute remains unresolved. In the case of China's maritime disputes, China's relations with the South East Asian states bordering the South China Sea are explored. The variance in China's actions in the South China Sea is argued to be understood as pertaining to the changing salience of China's perception of its self in relation to its fellow disputants in this region.

The contents of this thesis can be broken down as follows. The following chapter presents the methodology for the research undertaken. This chapter outlines the key tenants of the constructivist approach and the associated theories of ontological security, their application within the paper, and the benefits of this approach to the analysis of state borders more broadly. Chapter III provides a brief history of the disputes in question. These histories are presented in three parts, respectively detailing the nineteenth century Qing administration of the peripheral regions and the impact of European imperialism; the early twentieth century history of the disputes, initially under the failing Empire and subsequently under the Nationalist Government of China; and finally, the actions of the PRC, including settlements and ongoing negotiations up to the present day. Chapter IV provides a literature review for 
the topic, noting the existing scholarship and its shortcomings. Of note is the lack of studies which provide a concurrent analysis of China's maritime and land-based territory disputes. The strengths and weaknesses of, in particular, realist examinations of the disputes, and papers which touch on constructivist elements of the various disputes are also noted here. Finally, Chapter V outlines the main argument of this paper. This chapter provides an overview of the iterations of Chinese national identity relative to this discussion. Following this, the changing nature of Chinese identity in broader Chinese relations is discussed, identifying changes which align with periods of significance in China's territorial disputes. 


\section{Theory and Methodology}

This thesis draws on the constructivist school of International Relations theory, and accordingly, starts from the basis that China's interests, and consequently its actions in territorial disputes are based on the social identification China has of itself and of those it is engaged in disputes with. In short, 'interests [are treated] as endogenous to such interaction' as that between China and its neighbour states, and that this occurs 'as a consequence of identity acquisition, as learned through processes of communication, reflection on experience, and role enactment' (Reus-Smit, 2009, p. 223). Constructivism moves analysis of interstate relations away from the systemic, rationalist, and materialist issues of economic interdependence and the balance of power found in neo-liberalism and neo-realism, instead choosing to focus on normative and ideational aspects of those relations. Constructivist approaches to Asian interstate relations are limited in respect to Chinese foreign policy, where variables relating to realist and neo-realist theoretical approaches in particular are widely held to be the most relevant. The dominance of realist approaches in Asian studies occurs at the expense of liberalist ideas also. Neo-liberal and liberal theoretical approaches would assume that economic interdependence and international institutions would have a favourable effect on the settlement of territorial disputes (Burchill, 2009). However, existing scholarship widely regards Asia as lacking evidence supporting the viability of neo-liberal variables in the region (Goldsmith, 2007).

Realism, based on assumptions of state self-interest within an anarchic environment (Donnelly, 2009, p. 32), is widespread in analysis in relation to China. Writings such as those of Mearsheimer (2006), generally foresee an un-peaceful, aggressive and expanding state with growing power in China. The simplistic assumptions about territorial disputes which draw down from this school of thought are stark, and as noted above, largely incorrect given China's propensity to settle its disputes. Similarly, Waltzian neo-realism with its emphasis on the polarity of the international system - where states are compelled to align themselves based on their power relative to others (Donnelly, 2009, p. 36) - is a commonly used explanation for Chinese behaviour. Whether variables outside of the scope of liberalism and realism can account for China's decisions to settle some territorial disputes, while refusing to settle other (mostly maritime) disputes, is central to the questions asked by this thesis. 
Nevertheless, constructivism does not aim to dismiss the importance of these aforementioned theories in their entirety. Rather, this thesis aims to illustrate that the material aspects of interstate relations understood through the alternate major theories of International Relations can only occur within the context of social constructs. As Wendt puts it, 'materialists cannot claim power and interest as "their" variables; it all depends on how the latter are constituted' (as cited in Kratochiwil, 2006, p. 25). This constitution sees states act towards others based on the meaning they hold for that state, both in terms of their own self-identification and their understanding of the Other. Such understanding is developed through an ongoing process of participation in the international system which is informed by, and contributes to, state identities. For the constructivist, behaviours between states become predictable when a social act comes to create expectations of future behaviour through the repetition of signalling, interpreting, and responding towards others (Wendt, 1992, p. 405). Naturally then, the historical identification and interaction of states is central to understanding contemporary actions and expectations.

At times, states will engage in 'character planning', which may see their identity change (Wendt, 1992, p. 419), in turn changing their expectations, interests, and ultimately their actions and the actions of other states towards them. This idea is developed more fully in the process of ontological security seeking, which has been outlined by Mitzen (2006), and Steele (2008). In seeking to maintain ontological security, the security of the state's identity itself becomes its primary interest, rather than its physical security, which is more commonly emphasised in International Relations theory. For Mitzen (2006), this theory holds that states will act to secure their identities through the process of routinizing their interactions with external states (the Other). This provides states with a sense of agency, whereby decisions are able to be made based on a degree of certainty of the subsequent outcomes. Expectations for interaction are established through the established behavioural routine, which in turn informs how a state perceives itself in relation to the Other. In times of ontological security, these routines will remain consistent. However, behaviour from the Other which threatens the routine may result in ontological insecurity, causing the state to act to realign the interaction with its perceived sense of Self.

For Mitzen, identities are created and sustained through interaction with Others, whereas Steele expands on this, further suggesting that a state's identity is developed through its 'biographical narrative'. This biographical narrative is inherently bound to the state's 
historical narrative of the Self. This narrative comprises the 'sum of those forms of recall whereby the agent reflexively characterises "what" is the origin of his or her actions' (Steele, 2008, p. 55), and acts to provide "the locus through which agents "work out" their understanding of social settings and the placement of their Selves in those settings' (Steele, 2008, p. 71). For Steele, ontological insecurity can thus occur through internal changes to national identity, stemming from 'transformative possibilities [arising] not just between the Self and the Other, but within the internal dialectic that arises from the ontological security seeking process' (Steele, 2008, p. 32). In other words, a state will become ontologically insecure where its actions do not align with internal changes to its identity, causing it to change its interactions with others.

The application of the constructivist approach and ontological security to Chinese territorial disputes - and indeed territorial disputes in general - is, in fact, well suited given the nature of the social construction of state borders. It is clear from Wendt's seminal article on constructivism in International Relations, that the acceptance of 'territorial property rights' exists only in the context of mutual recognition of those territories (Wendt, 1992, p. 70). The point here is that state borders are an inherently ideational concept, developed through interactions with others. As such the analytical focus of constructivism is not only pertinent to national borders when they are being contested or are the subject of hostility either by governments or citizens, but at all times during their existence. Beyond physical boundaries, borders are 'signs of the eminent domain of that state [emphasis added], and are markers of the secure relations it has with its neighbours, or are reminders of the hostility that exists between states' (Wilson \& Donnan, 1998, p. 9). Likewise, if applied to territorial disputes, the process of ontological security can be seen to act in a number of ways, including through the maintenance or escalation of a dispute, as well as through its settlement. A change in the status quo of such a dispute (regardless of its status at that time) represents a change in the routine of the affected states, and therefore should be seen to arise from, or give rise to, a period of ontological insecurity. A state will therefore maintain this status quo unless its identity is threatened externally, or changes internally, causing its behaviour to change in order to regain ontological security. Dependent on the identity and the associated threat, this could occur through either settlement and cooperation, or aggression and conflict.

The importance of concepts of identity becomes especially obvious when applied specifically to the territorial disputes of China. A student of China's territorial disputes will not have to 
look far to discover the widely accepted importance of the historical borders of the Qing dynasty to the disputes of the People's Republic. In general, however, (as discussed in Chapter IV), the structural approaches to China's territorial dispute which prevail in existing scholarship recognise implicitly the existence of the historical social context to these disputes, while failing to give such context adequate attention in their analysis. Generally speaking, they therefore view borders as fixed variables rather than constructs which require contextual analysis in their own right. Such analysis is, at best, incomplete.

Instead, this thesis argues that this historical narrative can be identified in periods when the ontology regarding China's sovereignty over national minorities has taken on heightened ontological importance internally. External recognition of this sovereignty, by formally defining its limits through dispute settlement, which therefore reaffirms the existence of those inside these limits as part of the Chinese nation, acts to secure this ontology. Equally, maritime disputes are not settled as settlement would preclude China's historical identification in its position relative to disputant states, causing ontological insecurity. Where these states have threatened this routine, China has acted aggressively to maintain its ontological security, and has acted cooperatively due to internal changes to its Selfidentification. China's various actions in disputes have therefore all taken place within the context of China's identification of its past and present Self, its neighbours, and the interaction between these parts.

From this position, Wendt's statement that constructivists should question the 'what' and the 'how possible', where structural approaches are limited in their ability to explain the 'why', (as cited in Kratochiwil, 2006), requires application to Chinese territorial disputes. The central questions throughout this paper therefore include: what was the nature of the prevailing Chinese national identity at the time of the dispute in question? How did this identity relate to the territory in question? And how did China perceive itself in relation to the disputant state in question? Through examining how these differ and converge between various disputes, and how these variables manifest in diverging interests and actions, it is hoped that the application of these questions will illustrate why China has maintained a largely concessive pattern of behaviour in frontier disputes, contrasted with an uncompromising, relatively combative pattern of behaviour in maritime disputes. 
Having established the theoretical framework in which this paper will address its topic, the question of research methodology requires clarification. The approach taken here is that which Reus-Smit characterises as 'holistic constructivism', in that it seeks to give recourse to both the normative and ideational structure of the international system, and the social identities at the domestic state level (Reus-Smit, 2009, p. 225). Much of this paper relies on existing scholarship on Chinese territory disputes, Chinese national identity, and Chinese foreign relations in general, with limited use of primary documents (but their use where available nonetheless). Given the small sample size and the ideational variables central to this paper, the methodological approach taken to all sources is, by necessity, qualitative and interpretive. For those studies involving social identity and norms, where these concepts are irreducible to measurable units, interpretation becomes a constant necessity for the scholar (Kratochwil, 1988, p. 265). Attention is paid to the historical context as understood by the states themselves, not only of the disputes in question, but more broadly to the general interactions of the states in question. This analysis is undertaken in order to give meaning to the identity of a state through the examination of its 'biographical narrative'.

Finally, a comprehensive study of Chinese territory disputes is beyond the scope of this thesis, but an illustration of the importance of identity and norms in frontier or maritime disputes can be shown through selected case studies. The comparative nature of this paper requires case studies from both maritime and frontier disputes. While China has settled the majority of its frontier disputes, it is desirable to analyse both a frontier dispute that was settled without conflict, and one which has been ongoing and has involved conflict, in order to illustrate fully the process of ontological security. On its frontiers, China has held disputes with the Soviet Union (later Russia and various Central Asian states), Vietnam, India, Laos, Bhutan, Burma, Mongolia, North Korea, Pakistan and Afghanistan. Of these, Fravel suggests that the disputes with India and the Soviet Union are those in which conflict can be linked to the disputes with the most certainty (Fravel, 2008, pp. 63-64). For ease of analysis, the SinoIndian dispute has been selected due to the fact that the dispute has existed between China and only one other state throughout its duration, while the latter devolved into various disputes following the demise of the Soviet Union in the late twentieth century. The selection of the Burmese dispute from those remaining was ultimately made based on resource availability to the author. 
Maritime disputes include the disputed island groups of the South China Sea, and the Senkaku / Diaoyu island dispute with Japan. As the Senkaku dispute is one Chinese dispute which has been subject to constructivist analysis, much of which supports the arguments contained here (see chapter IV), the opportunity has been taken here to examine the South China Sea disputes, in order to extend this theoretical approach more broadly. Given the relatively late initiation of the Senkaku dispute by China in 1970 (Fravel, 2008, p. 334), analysis of the South China Sea disputes also allows for the most comprehensive analysis of the historical manifestations of China's identity relative to the disputes. Finally, unless required, the intention of this paper is not to provide detailed physical descriptions of the territories in dispute, but rather to assess the context in which Chinese behaviour has occurred. The following chapters provide a brief overview of the history of these disputes, before going on to assess the existing scholarship regarding them. 


\section{A Brief History of China's Territorial Disputes}

In September of 1949 the newly established People's Republic of China expressed its intention to study the treaties and agreements concluded between the Kuomintang and foreign governments, with the intention to 'recognise, abrogate, revise or renegotiate them' (Ginsburgs \& Pinkele, 1978, p. 1). Subsequent statements have made clear that this reference extended to all borders perceived as having been lost during the century preceding the establishment of the People's Republic. These losses were said to be the result of 'unequal treaties' undertaken with a weakened Chinese state by foreign imperial powers (Watson, 1966, p. 24). The purpose of this chapter is to provide a chronology of China's border history. To fully appreciate the context from which the PRC derived its claims, an understanding of the origin of China's border disputes beginning during the Qing Empire is required. This chapter begins with a brief overview of the nature of territorial holdings and their subjection to 'unequal' treaties during the so-called 'Century of National Humiliation' between 1839 and 1949. Following this, the PRC's responses to and management of the subject disputes of this thesis are explored.

\section{A Nineteenth Century Territorial History}

In his analysis of the origins of China's disputes, Lamb has expressed the view that the colonial powers of Britain, France and Russia, in changing the nature of external threats to China during the nineteenth century, made the modern Chinese state (Lamb, 1968, p. 69). This suggestion is not made with reference to treaties or border delimitation, but alludes instead to the nature of the periphery of China. This periphery - the outer frontiers of China comprised Tibet, Xinjiang, Mongolia and Manchuria, and was governed by central China through a complex tributary system. Prior to the mid-nineteenth century, these frontiers lacked formalisation into China proper, instead existing as protectorates with varying levels of autonomy. Within this system, China would receive tribute from visiting missions from the tributary regions, and these regions would in turn acknowledge dependency and the influence of China in their affairs. The significance of these outer borders to the Chinese state was dependent on the security of the central Chinese state against invasion from central Asian nomadic peoples. China's involvement in the governance of these frontier regions occurred only indirectly (Lamb, 1968, p. 32). An illustration of the importance of these frontier regions is found in the divergence between China's governance of the regions' outer boundaries (with foreign states), and the inner boundaries (those shared with China). Regarding the former, 
these were at times subject to change through agreement without involvement from the Chinese. Conversely, China carefully involved itself in the management of the latter (Lamb, 1968, p. 28).

The nature of the periphery in pre-twentieth century China can be found in the depiction of these areas in Chinese maps. While the outer regions of China had been mapped during the Qing dynasty during the seventeenth century during periods of imperial expansion, within these maps "“China" and the "Qing Empire" were not coterminous..."China" was presented as one distinct part of the Qing Empire, and the Manchu homelands [and later other periphery regions] another' (Elman, 2007, p. 49). These maps would later form the basis for some of China's territorial claims, yet at the beginning of the Opium Wars these regions were not understood to exist as a part of China in the same way that they would later be pursued in twentieth century territory claims (Lamb, 1968, p. 27). The extent of Chinese control over these areas varied leading up to the twentieth century. While the 'centre' of the Chinese Empire maintained an image of a unifying central culture in relation to populations and areas over which China maintained great interest and influence, such unity was unstable at best, varying in its success throughout nineteenth century Chinese history (Woodside, 2007). They were, however, a vital part of the Chinese Empire, and a significant and central part of Chinese identity.

By contrast, Chinese interest in its sea-borders waned during the Qing Empire. From the seventeenth to the eighteenth century, China focused predominantly on its land frontiers, including maintaining attention on an expanding Russia. Chinese intellectual thought (including its cartography) and its military would 'turn inwards' away from the maritime world, leaving the Empire with only a small coastal navy at the start of the Century of National Humiliation (Elman, 2007, p. 40). Evidence dating back to the 15th century particularly regarding fishing activities and naval patrols undertaken - is sometimes cited by the Chinese with regard to the South China Sea (Zhao, 2013). Such claims need to be regarded within the context of twentieth century territory claims and the international norms which legitimise these; it could hardly be said that these go as far as to suggest that the South China Sea was considered Chinese territory at any time prior to the twentieth century. While some Chinese ventured to sea for various reasons, as would come to be espoused within contemporary Chinese maritime claims, they 'were not the spearhead of Chinese territorial 
advance....and there is no evidence to suggest that Chinese officialdom ever considered them as such' (Lamb, 1968, p. 38).

Aside from the maritime regions, the border disputes which are the subject of this thesis continued to develop throughout the nineteenth century, though not in any formal way. Most significantly, the Chinese border with both India and Burma developed out of interactions between the British Raj, and was subsequently consolidated by Nationalist China and postcolonial India. The British did recognise Tibet as 'Chinese Tibet', in recognition of the protectorate status and influence of China over the region. Yet no border was delimited or demarcated at the time the British Empire expanded to the areas in question. Where attempts were made to establish formal boundaries, these were far from complete (Hyer, 1990, p. 115). Indeed, prior to the late nineteenth century the British did not actively pursue the establishment of borders. Rather, British interest in the establishment of borders coincided with threats to British economic interests, although this was to change in the early twentieth century.

The British maintained an awareness of the frontier regions between Tibet and India, areas which were largely tribal. However, a strict non-intervention policy was adhered to. The frontier of Tibet and Assam is illustrative here. The British adhered to the so-called 'outer line' of the frontier, within which various tribal peoples such as the tribes of the Tawang Tract were observed and understood to come under the sovereignty of Tibet. This outer line was south of the eventual contested border of the British established McMahon Line. When the British first began to move north from the outer line, it was at least in part an effort to wrest influence over these tribal people in the protection of economic interests in Assam (Lamb, 1964, pp. 133-139).

Unlike Tibet, where Chinese control varied throughout the nineteenth century, the influence of the Chinese Empire on the Burmese state had ceased in significance long before the introduction of British rule there. Following a failed military campaign into Burma by the Qing in 1790, Chinese conceptions of suzerainty were maintained as the Burmese rulers continued to pay tribute to Beijing (Hyer, 1990, p. 143). But Chinese claims to suzerainty over Burma proper which may have existed in the nineteenth century were interrupted by the British following their annexation of the state, ending with Upper Burma in 1886. Thus, the nature of the Sino-Burmese relationship was changed, and the introduction of boundaries was 
established, by the British. British rule would remain in place in Burma with the state first separated from India in 1937 and finally made independent from Britain in 1948 (Lamb, 1968, p. 147). In the last decade of the nineteenth century, the British began the process of establishing boundaries between China and Burma, with the two parties entering into agreement in 1894 and an additional supplementary agreement in 1897 which together largely delimited much of the border between China and British Burma.

In the process of expanding and consolidating their empire, the Qing asserted themselves heavily over the people of the Yunnan frontier, adjacent to the Burmese state. Yet despite this, their control over the local populations was never absolute, and was shared and negotiated with local authorities who would at times enter tributary relationships with both the Qing and the Burmese (Giersch, 1998, p. 15). Later in the twentieth century, at the time of the Burmese dispute settlement, this relationship would be characterised by the United States Department of State as being separated by a boundary which has been (Department of State, 1964):

Occupied by peoples of alien cultures. During most of their history, the Burmese and Chinese people were content to maintain these regions as buffers between states. National policy was based on non-interference in the affairs of tribal peoples while exercising only nominal suzerainty. (p. 4)

Alternatively, Chinese writers in the twentieth century became well versed in the legitimisation of Chinese dominance of local minorities through the portrayal of the frontier area as one steeped in central Chinese control, an 'inseparable part of the great ancestral land's domain' (Giersch, 1998, p. 13). The significance of this ambiguous Chinese influence, and its relationship with China's understanding of the area as internal to the Chinese state, will be explored more fully later in this paper.

\section{B Twentieth Century Territorial History}

While Chinese allusions to the 'Century of National Humiliation' suggest a long period of exploitation, it was during the early twentieth century that points of reference for competing claims in the Indian and Burmese borders were created. In 1905, following the agreements of the late nineteenth century, the Sino-Burmese boundary was subject to a joint survey and a convention on the matter was signed by the two states in the following year, during which the 
British acknowledged Tibet as being included within Chinese territory (Maung, 1961, p. 39). In 1910, as Chinese influence on the frontiers weakened, Chinese troops occupied Tibet as the Qing sought to incorporate Tibet into the Chinese provincial system. During this time Chinese efforts to subjugate Mishmi tribal people caused British suspicion to focus on Chinese interests in the Himalayan Assam area in the eastern sector of the frontier with India (Lamb, 1964, pp. 127-142). Tibetan independence was declared internally in 1912 when the collapse of the Chinese Empire was followed by the subsequent withdrawal of Chinese forces from Tibet (Watson, 1966, p. 55). As British fears of Chinese involvement in the area had been alleviated, the British moved to consolidate their interests in the area by establishing Tibet as a buffer state in 1913, and initiated the Simla Conference on the pretext of confirming the nature of Chinese involvement in Tibet.

The Simla Conference of 1914 was a crucial point in the history of the Sino-Indian border dispute. Ultimately, the Chinese could not agree on the establishment of a Chinese inner and independent outer Tibet, which was the intent of the conference. Consequently, initial Chinese acceptance of the Simla agreement was later repudiated by the Chinese Government in objection to the borders suggested between the inner and outer zones. Despite Chinese rejections of the conference talks, borders between Indian Assam and Tibet were subsequently devised at the conference by Sir Henry McMahon, the British delegate who would ultimately lend his name to the boundary. These boundaries were agreed to by the Tibetans, but without Chinese involvement (Lamb, 1964, pp. 143-147). The boundaries agreed by the British and Tibetans would not be published until the 1930s, and their existence was never included in any Chinese maps. Nevertheless, the McMahon Line significantly increased Indian territory as recognised by the British, beyond the previously adhered to 'outer line'. Parts of the McMahon Line also extended into the Sino-Burmese border in the east, and would be subject to renegotiation under the PRC later in the century. The McMahon Line would be inherited by independent India from the British and would remain the basis for much of the Indian claim in the eventual dispute with the PRC.

At this time the current Chinese claim to the South China Sea began to be represented on Chinese maps through the so-called 'nine-dash line', dating to around 1914. While initial claims to this area were limited to two of the four island groups in the South China Sea, the scope of Chinese claims would later extend as interest in the area increased (Gao \& Jia, 2013, p. 100). In the South China Sea, the full extent of Chinese claims had been determined prior 
to the establishment of the People's Republic with the nine-dash line, including all features within the Sea included in official government maps from 1947 (Zhao, 2013, p. 29). The Chinese claim to this area is, therefore, noted to contain the entirety of the South China Sea, the islands therein and the adjacent waters.

The question of the Sino-Burmese border was revisited between 1935-1937 under the auspice of the League of Nations, during which time a committee was established to determine the delimitation of the Wa state region in the southern sector of the border. The work of this committee was eventually signed in 1941 in an Anglo-Sino agreement, but demarcation of the agreed boundary was never completed (Department of State, 1964, p. 5). The agreement was undertaken to clarify the border previously established unilaterally by the British and sought to clarify rights regarding Chinese and British mining interests in the Wa state region. The Nationalist Chinese government, having signed the 1941 agreement, would go on to challenge it and call for renegotiations in the post war years (Lamb, 1964, p. 157). The 1941 agreement would later be held by the PRC as an example of the exploitation of a weak Chinese government by imperial powers, and deemed an unfair and illegitimate agreement.

Following World War Two, decolonisation and the subsequent successors of imperialism began to influence interstate competition in the island groups of the South China Sea. The withdrawal of imperial powers from the area either transferred territory to newly independent states, or left territory without clear ownership. This would consequently sow the seed for multilateral territorial disputes in the South China Seas, as Japan gave up all rights to the area through the San Francisco Peace Treaty of 1951. The treaty saw Japan renounce sovereignty to their Spratly and Parcel Island holdings, with no clear indication given as to whom ownership of these islands would be transferred (Hara, 2012). France had maintained a presence on both the Spratly Islands and the Parcel Islands during the height of its South East Asian colonisation. While not coerced into its losses, the cost of World War Two and the difficulty of maintaining colonies in the post-war years saw France reduce its occupation to only the Spratly Islands. As interest in the territories in the South China Sea grew in the twentieth century, the lack of clarity in ownership, the hangovers of both Asian and European imperialism, and the potential for, and legitimacy of, economic exploitation would feed into the divergent maritime claims of South East Asian states. 
By the advent of the PRC in 1949, the foundation of China's territory disputes had been laid, but was far from being formally expressed. The extent of territory in question at the boundary shared between Tibet and India included the regions of Aksai Chin at the western sector of the border, and the Assam/Tibet border in the eastern sector. Within this claim, approximately fifty thousand square miles of disputed territory existed to be claimed by the Chinese (Lamb, 1964, p. 9). The Chinese claim to territory in Burma equated to roughly ten thousand square miles, and could also be divided into several sections; in the northern sector of the border the Kachin region, the Nanwan Tract in the middle section of the border, and the disputed areas in the Wa state region (Hyer, 1990, pp. 151-153). In the South China Sea, China's claim remained that which was represented in the nine-dash line.

\section{Disputes of the People's Republic of China: 1949-Present}

While the newly established Communist government of China had made clear their intentions regarding China's borders in 1949, the 1950s saw a slow approach to undertaking formal talks regarding those borders, and settlement of the disputed borders was not a high priority for the Chinese. However, for the PRC, the 1950s was an important decade in the borderlands, and particularly in Tibet. While formal delimited and demarcated borders may not have been devised during the 1950s, the border disputes must be understood within the context of broader events during that decade. In 1950 the PRC began the re-incorporation of the Tibetan state into the China, defeating ethnic Tibetan forces in the eastern Tibetan region, leading to agreement from Lhasa on the incorporation of Tibet into the PRC. The 1950s in Tibet were characterised by this ongoing incorporation, upheld in the '17 Point Agreement' under which Tibet retained its political systems and the authority of the Dalai Lama remained in place, but China took control of Tibet's foreign relations. Rule in Tibet therefore remained indirect, and attempts at assimilation of Tibetan nationals into China were ultimately far from successful (Fravel, 2008, pp. 73-75). Ethnic uprisings against the Chinese government would first occur following changes by the Chinese to the Tibetan political system in the mid-1950s, taking place in rural Tibet and abutting regions including Yunnan and Xinjiang. In 1958 these revolts spread to Lhasa, culminating in the Tibetan crisis of 1959. The forces of the People's Liberation Army (PLA) forcefully suppressed Tibetan rebels; Tibet's political system was removed and replaced with Chinese governance through the prefecture system; and the Dalai Lama fled the region, taking refuge in India (Fravel, 2008, pp. 75-79). 
The Tibetan border with India had its initial appearance in Chinese foreign policy following the 1950 'liberation' of Tibet by the PRC, and acted indirectly as the catalyst for Sino-Indian discussion on the border dispute. On regaining authority over the formally independent Tibet (independence considered invalid by the Chinese), the PRC renounced those treaties entered into or maintained by Tibet with its Indian neighbours. Recognising that they would need to accept Chinese authority in Tibet, India met with China in 1954, the result of which was an agreement between the two states which allowed for India's continued economic and cultural ties to Tibet, and Indian recognition of China's sovereignty over Tibet (Hyer, 1990, p. 119). The nature of the Tibetan border was raised only indirectly at the 1954 negotiations, arising in discussions relating to trading routes across the border, but no meaningful discussions were undertaken as to the location of that border, or even to the recognition that the border was in dispute.

The 1954 agreement represented the beginning of a brief cordial period in Sino-Indian relations. Only months after the agreement was signed, the well-known 'Five Principles of Peaceful Coexistence' was adopted for the relationship between the two states. These principles, which would shortly thereafter enter into China's foreign policy in Asia more broadly, consisted of mutual respect for other's territorial sovereignty; mutual nonaggression; non-interference in another state's internal affairs; equality and mutual benefit; and peaceful coexistence (Ogden, 2013, p. 260; Watson, 1966, p. 83). Yet for the majority of the 1950s these principles were insufficient to allow for progress in the dispute, which instead went unmentioned. However, the publication of Chinese maps which included Indian or Burmese territory (or the territory of other states) represented as Chinese would at times draw protests from India, who continued to recognise the validity of the McMahon line. From China, these protests would elicit a response which would invariably note that the maps should not be viewed as official Chinese claims, and that China had not yet reviewed the background of the borders and so was not yet prepared to comment on them (Watson, 1966, p. 81). Clarity on China's claims on the border would not be realised until 1959.

A primary point of tension with India arose through the building of a Chinese road through the Aksai Chin region in the western sector of the border, connecting the autonomous Chinese border regions of Xinjiang and Tibet. The region had been used by the Chinese to facilitate their reoccupation of Tibet in the early 1950s, and the road had been subsequently built between 1956 and 1957. The road, being the only connection between the two Chinese 
regions, was seen as one of significant strategic importance to the Chinese. However, its appearance in an area which had never been formally delimited, and was considered by the Indian government to be Indian Territory despite Chinese control of the area, alerted India to Chinese claims to the region (Hyer, 1990, pp. 125-126). For India, the dispute they had understood to be confined to the legitimacy of the McMahon line was expanded. Tensions also arose from Chinese activities beyond what was considered Indian Territory in the eastern sector, leading to a minor confrontation along the border in 1959. Similarly, during the 1950s, the PLA would occasionally venture across into territory claimed by the Burmese, in pursuit of Nationalist Chinese militants, much to the protest of the Burmese (Watson, 1966, p. 80).

While border talks were not a high priority for China along its frontiers, increasing interest in the South China Sea territories from other states forced China to take notice of its maritime claims. In 1956 the first clash over the area since the Second World War would occur following Filipino involvement in the area. Two Filipino citizens acted to claim fifty three features of the Spratly island group, including Itu Abu, the largest feature, only to ultimately be expelled by a Taiwanese naval flotilla (Raine \& Le Miere, 2013, p. 40). Prior to their expulsion, China aggressively restated their claim to the entirety of the South China Sea. But it was only once faced with such competition from neighbouring states that these claims were restated by China. This competition was exacerbated following France's withdrawal from the region in the same year and the subsequent inheritance of French holdings in the Paracel islands by South Vietnam. It is notable that the PRC did not maintain an open dispute with imperial France. Instead, their reassertion of ownership was undertaken in the context of competition with newly independent Asian states.

From late 1959 until the mid-1960s, China would enter into a period of widespread settlement along its continental borders, settling disputes with Burma, Nepal, North Korea, Mongolia, Pakistan, and Afghanistan (Fravel, 2008, p. 45). It was in 1960 that the Chinese also offered a 'package deal' to India. The deal consisted of Chinese recognition of the border represented by the McMahon line (though not the validity of the Simla agreement) in the middle and eastern sectors of the Indian border, in exchange for concessions from India in the recognition of the entire Aksai Chin areas as Chinese. Nevertheless, the deal was rejected by India, which was resolutely opposed to conceding territory to the Chinese (Hyer, 1990, pp. 133-135). Conversely, the Burmese settlement, first signed on 23 January 1960 following only five days of negotiations, was held as the shining light of Chinese territorial negotiation 
(Watson, 1966, p. 127). The Burmese settlement was the first to be formally undertaken by the People's Republic, having occurred at the request of the Burmese. The settlement occurred following a period from 1953 in which the forces of the PLA were stationed along the Burmese border following the withdrawal of Nationalist forces into the Burmese state. The presence of these forces is noted by some scholars as a factor in Burma's cooperation (Lamb, 1968, p. 151; Watson, 1966, pp. 89-94), yet the Burmese emphasised that cooperation had occurred under the free will of both states. For their part, the Chinese proclaimed the settlement a demonstration of friendly Burmese-Sino relations, and a 'brilliant example' of peaceful coexistence which other disputant nations and China should aspire to recreate (Maung, 1961, p. 38).

Notably, the Burmese settlement resulted largely in recognition of the status quo, including a small section of the McMahon line on the Burmese border. The recognition of these borders by the Chinese government occurred despite two key points; the first being the use of maps by the CCP which recognised large parts of northern Burma as Chinese. The second was Burma's acknowledgement of the boundary as being 'inherited from history, a product of imperial politics of aggression', and therefore the subsequent need for their renegotiation; a statement in line with Chinese claims that the border was void having been founded in an unjust treaty (Maung, 1961, pp. 38-40). Ultimately the Chinese claim was reduced significantly to facilitate settlement, with concessions against their original claim of some ten thousand square miles ending in only fifty square miles of additional Chinese territory. It is clear then that the Chinese goal in this settlement was not large amounts of territory, nor the exploitation of this territory, given that Chinese rights to 'participation in mining enterprises' were renounced (Department of State, 1964, p. 9). Neither, evidently, was the goal to reclaim territorial boundaries which were viewed as previously part of the Chinese Empire.

The terms of the agreement were largely based on sovereignty over border peoples. The villages of Hpimaw, Gawlum and Kangfang, and the tribal areas of Panhung and Panlao were turned over to the Chinese, as were the Yawng Hok and Lungnai villages (Department of State, 1964, p. 7). The two latter villages were provided to the Chinese as a point of administrative clarification in the Wa state region of the border. The 1941 line established between the British and the Nationalist Government had dissected several villages, of which two were clarified as Chinese, and four recognised as residing within Burma (Lamb, 1968, p. 156). Those villages incorporated into China had been claimed by the British early in the 
twentieth century despite Chinese protests, although Chinese rights to these villages were recognised in the offer of the British to lease control of them from China (Maung, 1961, p. 40). Also previously leased by the British, but now 'gifted' by the Chinese to Burma, was the Nanwan Tract, an area through which a Burmese highway ran. The Tract was exchanged for the Chinese claim to the area of the Wa state region.

Despite the example of the Burmese settlement being promoted by the Chinese, the Indian dispute proved challenging to outwardly friendly Sino-Indian relations. The Tibetan crisis in Lhasa in 1959 had seen these relations breakdown following the amicable period of the 1950s. The suspicions of Mao that India was in collusion with the United States in an effort to undermine Chinese sovereignty in Tibet (Garver J. W., 2004, p. 10), were exacerbated by Indian acceptance of thousands of Tibetan refugees, famously including the Dalai Lama. Assurances that the Dalai Lama would not undertake political actions against China from India were proven groundless (Maxwell, 1970, p. 105). In 1959, Chinese and Indian forces exchanged fire along the border, following moves by both sides to establish military posts within disputed areas (Maxwell, 1970). Despite these tensions the Chinese nevertheless pursued settlement in the dispute, leading them to instigate the unsuccessful negotiations in April 1960 in which the 'package deal' was offered.

The dispute was intensified by India when the 'forward policy' was adopted by Nehru in 1961, involving the advancement of forces of the Indian Army into disputed Chinese territory and the establishment of outposts in an effort to force the Chinese out of these areas. By 1962, the forward policy had resulted in various small engagements between forces of the PLA and the Indian Army. The forward policy was predicated on the assumption by the Indian government that the Chinese would not resort to full scale force. Yet increasingly, and in light of India's continued refusal to negotiate on the issue, China would respond to Indian expeditions into disputed territory with warnings that military involvement would occur should the actions of the Indians not cease (Maxwell, 1999). In 1962, the potential of these tensions was realised in a brief but significant border war between India and China.

The Sino-Indian border war occurred following a rise in tensions in the eastern sector of the border in October of 1962. While China had been increasing its forces in both the western and eastern sectors without resorting to full scale conflict, tensions came to a head in the eastern sector along the disputed Thag La ridge (Fravel, 2008, p. 190). The Indian claim in 
this area extended north of the McMahon Line, following the ridge line instead of the agreed coordinates of the Simla agreement, based on what India claimed was McMahon's original intention. Indian confidence in its own strategic advantage in the area, and resolute political and public belief that China were advancing on Indian territory, led Nehru to publically announce on the $12^{\text {th }}$ of October that Indian forces would undertake offensive actions against Chinese forces, focussing on the Thag La ridge boundary (Maxwell, 1970, p. 302). However, Indian confidence was severely misplaced, and Nehru's statement was viewed by Beijing as absolute. On the twentieth of October the PLA began a month long offensive against Indian forces along the full extent of the Sino-Indian border. Indian 'forward policy' posts were overwhelmed and Indian military forces experienced heavy loses. The Chinese offensive was punctuated by additional offers from the Chinese to negotiate on the boundary question, offers which were rejected by the Indian government (Maxwell, 1999, p. 913).

China's advance into the disputed territory was followed by a proposed ceasefire from the Chinese, in which Chinese troops would not only withdraw from disputed territory, but would further withdraw twenty kilometres back from the disputed McMahon line (Maxwell, 1970 , p. 417). Ultimately the Chinese withdrew promptly and unilaterally on the $22^{\text {nd }}$ November 1962, without any demands to retain the territory which they had advanced into, an action which came as a surprise to many observers at the time. As summed up by Hyer, the Chinese position 'clearly demonstrated that China was not bent on territorial expansion, but sought a boundary settlement and had undertaken the invasion in an attempt to force India back to the negotiating table' (Hyer, 1990, p. 137). This strategy was ultimately far from being successful. Instead, following the war of 1962, the Sino-Indian border dispute remained intact but went unaddressed for another twenty five years. Far from resuming negotiations, Indian anti-Chinese sentiment was consolidated by the border war, and in response India cut communications with Beijing until 1967. Nehru's diplomatic position on the dispute remained unchanged in perpetuity, although with varying degrees of zealousness; compromise on the boundaries claimed by India was not an option. However, the forward policy which had been so significant in the lead up to the 1962 war was removed, the Indian army withdrew from the area, and border tensions were largely alleviated (Maxwell, 1999, p. 914).

Despite knowledge of Chinese claims to the area, in the South China Sea hostility was kept to a minimum. During the 1950s, Chinese fishermen operating within the Paracel Island group 
occasionally came into contact with South Vietnamese vessels, resulting in the removal of the fishermen from the area (Fravel, 2008, p. 274), an action characterised by the Chinese as kidnapping and abduction. Yet, aside from the claims to the region noted above, activities by China regarding its claim remained absent until the 1970s. In the intervening year the interests in the South China Sea from various independent states had begun to be intensified within the emerging context of the United Nations Convention on the Law of the Sea (UNCLOS) and the associated economic rights that entailed (Hara, 2012). This new international maritime context saw the occupation of features in the Spratly Island group by both South Vietnam and the Filipino Government; an island group claimed by China but of which it had no territorial holdings.

Conflict for China in the South China Sea did not occur until January 1974, in the Battle of the Paracels, a brief naval conflict against South Vietnam. While the conflict caused loss of life on both sides, the South Vietnamese were ultimately unable to maintain their presence when an appeal for United States' support failed. South Vietnam relinquished its territorial holdings in the Paracels to China following the conflict, and subsequently all remaining South Vietnamese claims were absorbed by the unified state of Vietnam in 1976 following the conclusion of the Vietnam War. Tensions in the region would continue both with and without Chinese involvement during the 1970s. Despite losing territory in the Paracels, through forcing the Philippines out of the Spratly Island chain, Vietnam would eventually gain control of twenty seven features within the Spratly group (Raine \& Le Miere, 2013, p. $33)$.

Following a period of relative inactivity on the Tibetan frontier, during the 1980s SinoIndian, interaction on the border dispute was reinstated. From the early 1980s China and India undertook a series of Eight-Round border talks intended to re-engage negotiation on the border issue. The talks highlighted the continued position of China regarding settlement through compromising on the package deal proposed in the earlier negotiations. While India ultimately agreed to allow negotiations to proceed, the uncompromising position of India remained unchanged. The talks ultimately resulted in a determination to improve Sino-Indian relations through alternate measures to dispute resolution, including improved diplomatic and economic relations (Liu, 2011, pp. 153-154). While good-will relationships improved on the border, Indian military involvement in the same location as had sparked the 1962 conflict, threatened to draw the states into conflict again in 1987. China would not be drawn into 
conflict as it had been decades earlier and, despite the hostility on the border, the established diplomatic measures continued nevertheless.

Following this, India and China entered an unprecedented period of cooperation and understanding regarding the border. This began with visits of the countries' respective Prime Ministers in 1988 to discuss the border, with the decision to establish a joint working group being made at this time. Diplomatic visits continued, with Li Peng requesting the move towards settlement be expedited from 1991 (Fravel, 2008, p. 169). Renewed negotiations led to an eventual agreement between the two states in 1993, which recognised the status quo of the boundary in the 'line of actual control', and reaffirmed India's recognition of Tibet as a part of China. That the dispute was not resolved, however, was noted in the agreement through the understanding that recognition of the line of actual control did not 'prejudice respective positions on the boundary question' (Maxwell, 1999, p. 916). A further 1996 agreement promoted friendly relations through the inclusion of articles agreeing not to use force in the dispute, and reduced military presence on the border to a level compatible with friendly relations (Maxwell, 1999, p. 916). Additionally, in 1996, China once again reiterated its 'package deal' offer to India, but without success (Fravel, 2008, p. 169).

While China was building confidence with its Indian neighbours, in the South China Sea tensions rose in the late 1980s and early 1990s. In 1988 China re-established territorial holdings in the Spratly Islands. China's occupation of Spratly Island features acted as the catalyst for the Battle of Johnson South Reef with Vietnam, and resulted in the death of seventy-four Vietnamese seamen (Raine \& Le Miere, 2013, pp. 41-44). China further expanded its territorial holdings in the Spartly Islands in 1994 with the occupation of Mischief Reef. Diplomatically, tensions increased in 1992 when China's National People's Congress signalled the significance it gave to the dispute by passing a territory law which declared the South China Sea as Chinese internal waters. This law reasserted China's claims under the Chinese interpretation of the provisions of UNCLOS. Additionally, through passing the law, China internally legitimised the potential use of force within the region, including in the identification of vessels and submarines, and the eviction of unfriendly vessels from the disputed area. The response from ASEAN nations which reciprocated the Chinese indications was unsurprising, with disputant states assuring China that violation of their sovereign territory with military force would be met in kind (Buszynski, 2003, p. 347). 
From the mid-1990s China shifted its policy towards the rival claimant states from insistence on bilateral negotiation (seen as favouring China's relative economic and military power in the region), to cooperative multilateral talks. In response to China passing the territorial law, ASEAN states expressed the desire to develop a code of conduct to protect them against the growing threat from China. Beginning in 1995, China began negotiations with ASEAN over a proposed code of conduct for the South China Sea. The code of conduct would prevent further expansion by claimant states in the area and would provide the basis for multilateral cooperation over resources within the area. Drafted primarily by China, the Philippines, and Vietnam, the proposed code allowed ASEAN to gain greater regional integration and stability against the relatively powerful China; and also allowed China to guard against an intensification of United States influence among ASEAN states. The agreement was eventually reduced from a legally binding document to a declaration of principles, which followed controversy around the definition of the disputed area, and the prevention of military activity from external states. Ultimately, the Declaration on Conduct was signed at the $8^{\text {th }}$ ASEAN summit by ASEAN and China, in November 2002 (Buszynski, 2003, p. 347).

The twenty-first century has seen the improved relations between India and China involve several assertions by India to the recognition of Tibet as an autonomous region of China. Despite occasional tensions and threats of violence along the border since 1996, the status quo in recognition of the line of actual control has not changed. Liu characterises the period of improved relations in the 1990s between India and China as bookended by the promise of the 1988 Prime Ministerial visit to Beijing, and the 1998 Indian nuclear tests (Liu, 2011, p. 155). Yet given the general maintenance of the status quo of the border since the agreements of the 1990s, the significance of the nuclear tests on the border dispute itself is debatable, as is the significance of other high level interstate relations removed from the issue of the border dispute. Ultimately, the border issue has remained unresolved despite apparent joint efforts to address it.

Likewise, the ostensible move towards resolution in the South China Sea dispute appeared to be realised with the establishment of two further agreements, though to date little meaningful resolution has been achieved. The 2003 Treaty of Amity and Cooperation, which saw ASEAN and China pledge not to undertake any action which could threaten the stability of the region, and the trilateral Joint Marine Seismic Undertaking (JMSU) signed between China, the Philippines and Vietnam in an effort to undertake cooperative resource 
development, brought with them a sense of ease for the region. These agreements provided only a temporary reprieve from tensions. However, 'it was increasingly clear that the fundamental underlying lack of trust among the parties was continuing to encourage the militarisation of these disputes' (Raine \& Le Miere, 2013, p. 48). Subsequent legal approaches to the dispute have done little to aid its resolution. Submissions to the UN on continental shelf claims originating from the Philippines, and from a joint submission from Malaysia and Vietnam, resulted in protests from China, urging its members not to consider such a submission (Communication received with regard to the joint submission, 2009). Recent attempts by the Philippines to initiate arbitration regarding maritime delimitation in the South China Sea have also been rejected by China, who has reiterated its 'indisputable sovereignty' over the region based on historical activities and mapped in the nine-dash line from before the establishment of the PRC (Chinese government's Position Paper, 2014).

Finally, China has also had minor clashes with both Vietnam and the Philippines over the disputed area in recent times. In March 2011, two Chinese fishing vessels shadowed an oil exploration ship from the Philippines, and in May of the same year cut the towing lines of equipment used by two Vietnamese ships looking for oil on separate occasions, once through the use of a Chinese paramilitary vessel, and once through the use of a fishing vessel (Raine \& Le Miere, 2013, p. 49). China has also used weapons to intimidate fishermen from both countries operating within the disputed area (Sutter, 2011, p. 68). In April 2012, China used military intimidation against the Philippines in an area subject to dispute, briefly resulting in an embargo being placed on Filipino banana exports and a blockade of Filipino ships from the area (Goh, 2012). In 2014 Chinese and Vietnamese vessels collided over oil exploitation rights in waters disputed by the two states (Vietnam and China ships 'collide in South China Sea', 2014). 


\section{Literature Review}

Existing literature on the topic of Chinese territorial disputes is considerable, however comprehensive comparative analysis of various disputes and the reasons for associated Chinese behaviour has been limited to date. Studies of individual disputes, particularly those which were longstanding or remain unresolved (India, the South China Sea, Japan) are notable for their prevalence, particularly in non-academic writing. Noting that the purpose of this thesis is to provide a comparison of maritime and frontier disputes, the intention of this chapter is not to provide comprehensive coverage of all existing literature on the various individual disputes. Instead, an overview of the common academic perspectives and theoretical approaches applied to the study of China's territorial disputes will be provided. Where comparative studies of various disputes have been undertaken, these will be explored in more detail.

International Relations approaches to the disputes predominantly draw on realist approaches. These are themselves focussed on neo-realist concepts of external threats and state alignment in the international system, rather than on the more classical realist considerations of state expansion and economic and territorial self-interest. China's predominantly concessionary behaviour and the relative unimportance of much of the land in dispute largely preclude analysis typical of classical realism. Predictions of an expansive China sustained by growing state power are not supported by historical concessions which conceded large tracts of territory to smaller, weaker states, as with Burma. Furthermore, briefly setting maritime disputes aside, much of the territory in question here is sparsely populated hill country offering few material benefits (Department of State, 1964, pp. 1-2; Fravel, 2008, p. 50). The obvious exception to this is the Aksai Chin area, which held strategic importance to China due to the roadway connecting the regions of Tibet and Xinjiang. However, classical realist concepts which assume a state will expand where possible cannot explain why the Chinese would incorporate Aksai Chin into negotiations with India. Given that Chinese control over Aksai Chin was already established long before the dispute, little material gain could be made through such an approach.

In line with the theories of Waltz and other neo-realists, a number of authors have argued that China's behaviour can be viewed as being influenced by its alignment in the international system. Of note here is Hyer (1990), who is one of the few authors to have undertaken a 
systematic study of various Chinese disputes. Hyer argues that the central determinant for Chinese behaviour should be seen as being the triangulate alignment of India, China, and the Soviet Union. For Hyer, China's behaviour 'can be explained by the hypothesis that the PRC's approach to a dispute is determined by its perception of the balance of power in the region, acute threat perception and corresponding foreign policy which in turn determines policy towards a specific dispute' (Hyer, 1990, p. 7). For the disputes relevant to this paper, settlements in the early 1960s are understood to have been made in pursuit of higher-level regional alliances rather than any kind of territorial integrity, which is the subject of the disputes (Hyer, 1990, p. 23). Proposed settlement with India and settlement with Burma are classed as actions undertaken within the context of China's worsening relationship with the Soviets and Chinese fears of the Soviet Union's increasingly good relations with India. Conversely, war with India is seen by Hyer as the result of a Chinese response to continued Indian pressure through the forward policy, with the swift resolution of the war seen as reflective of China's concern of the threat from the Soviet Union and a disinclination to 'get dragged into a quagmire in India also' (Hyer, 1990, p. 136).

Similar realist orientated studies can be found in those of Sun and Huang (2012) and Nie (2009). Respectively, these studies emphasise the importance of the encirclement of China by regional great powers, and the interrelationship of external states' foreign policy as either revisionist or status quo states. Like Hyer, these authors broadly view external pressures and regional balance of power considerations as central to the Chinese decision-making process. Neighbouring states can be seen to be soliciting behaviour from China by acting with status quo or expansionist characteristics, resulting in Chinese concession of escalation or disputes respectively. The strength of China's actions is seen to be based on the increase of Chinese power compared to those states with which disputes are shared. Maxwell (1999) draws similar (though more nuanced) conclusions when examining the Sino-Indian dispute specifically, assessing China's decision to use force against India as the result of India's continued aggressive use of the 'forward policy' and unwillingness to compromise, policies which presumably appeared to the Chinese as 'expansionist'.

An alternative approach sees the settlement and escalation of the disputes as an action which provides a means to other foreign policy ends, described by Wiegand (2009) as issue linkage' and 'coercive diplomacy'. Such an approach can be found in Watson (1966), who argues that concession against broad, irredentist claims with smaller states served to allow 
China to coerce the more powerful India and the Soviet Union. This is attempted, though unsuccessfully in the case of India, by establishing an image of China as conforming to the 'Five Principles of Peaceful Coexistence'. This characterisation is given to the Burmese settlement by Watson. Furthermore, Watson highlights the need for the Chinese to refuse acceptance of the McMahon line, lest they implicitly accept the twentieth century sovereignty of Tibet as an independently party to the Simla conference (Watson, 1966, p. 91). Yet while it is certainly true that the Chinese sought to draw on the image of peaceful and cooperative Asian relations, such an analysis does little to illustrate why the areas exchanged in the Burmese agreement were chosen, nor why maritime disputes have failed to be settled.

Issue linkages have been raised by other authors in relation to China's other disputes. Wiegand (2009) has argued that coercive diplomacy and issue linkage are central to understanding China's strategy in its dispute with Japan over the Diaoyu / Senkaku Island group. Wiegand states that 'China has been able to take advantage of the endurance of its territorial dispute with Japan and use it as bargaining leverage to achieve shifts in Japanese foreign policy regarding other disputed issues' (2009, p. 171). Garver (2011), associates the continuation of the Sino-Indian dispute with Chinese deterrence of Indian interests in Tibet more generally. For Garver, the importance of the dispute for both India and China is the role of those State's nationalism in perceiving Tibet as being within their sphere of influence. For China, maintenance of the border dispute allows pressure to be exerted on India when it appears the latter is overreaching in Tibet. While it is not clear in this interpretation why China so steadfastly pursued settlement through concession throughout the dispute, Garver's arguments offer one of the most explicit appeals to concepts of national identity outside of constructivist literature, and largely support the arguments made later in this paper.

As with many of the articles listed above, it is commonplace for scholarship of Chinese territory disputes to focus on individual disputes (Fravel, 2008, p. 4), or to compare frontier disputes while choosing to leave maritime disputes unexamined. Fravel's work on the topic represents the notable exception to this, and provides an interpretation of the discrepancies between the two types of dispute. As such, extended discussion of this work is worthwhile here. For Fravel (2008), state behaviour in territorial disputes is determined by internal threats and regime stability in instances of cooperation and concession, and in the relative bargaining power of a state (territorial holdings and force projection), of which a decline leads to instances of aggression. Accordingly, concessions made to India and Burma are said 
to derive from the need for assistance from these states to maintain control over Tibet following the 1959 crisis. Alternatively, when Fravel addresses China's maritime disputes his emphasis turns to the as yet unrealised economic and energy exploitability of the South China Sea (2008, p. 276). Maritime disputes are noted as being delayed in response in order to maintain access to this potential exploitability, with moments of escalation occurring as disputant states expanded their holding throughout the late twentieth century.

The appeal to the economic and strategic significance of the South China Sea is common. Further scholarship which supports this view can be found in the work of Garver (1992), who argues that while Chinese interest in the region was previously motivated by strategic concerns, it has since moved to the pursuit of economically exploitable resources based on maritime claims and concerns regarding continental resource limitations. Likewise, Zhao (2013) views China's energy needs and oil resources in the region as a key behavioural driver in the dispute. Such analysis typically views the economic benefits of the region with the ability to claim exclusive economic zones (EEZ) under the provisions of the UNCLOS, allowing for control over the associated fisheries and energy resources. Yet the establishment of an EEZ unrecognised by the international community is unlikely to provide easily exploitable rights for China, which would be required for the impact of UNCLOS to have significance. The immediate salience of energy resources for China is also low, with the majority of China's energy coming from coal or alternate sources of oil (Curtis, 2014). China's best option for the exploitation of these resources, without the use of force, would be through cooperation with neighbour states, cooperation which has been limited and undermined to date.

Furthermore, neo-realist arguments in favour of regional alignment in the South China Sea are also undermined by recent actions of hostility, which have coincided with increased attention in the region from the United States. Were Chinese concessionary behaviour aligned to its relative position within the international system, the signalled 'pacific rebalance' of the United States should have instead resulted in cooperative behaviour from China with smaller South East Asian states to prevent their alignment with the opposing great power. Instead, aggressive military and diplomatic Chinese behaviour has resulted in renewed military ties between the United States and disputant countries Vietnam and the Philippines, further limiting the strategic gains China could potentially realise in the region (Curtis, 2014). 
Another shortfall of Fravel's analysis, and of the approaches examined above, is the inability of these approaches to explain the significance and instigation of the PRC's disputes without drawing on ideas of historical national identity. Where the importance of these variables is noted, these are often dismissed in favour of approaches limited to examining the subsequent behaviour of China in existing disputes. Speaking from a theoretical perspective, the dismissal of ideational variables in Fravel's analysis leaves this work significantly incomplete. While Fravel addresses ideational variables, he views these solely from the point of view of international norms, specifically the prevalence of the norm of respect for territorial sovereignty following World War II. Fravel dismisses this view as being unable to account for when concessions of territory are given (2008, p. 25). Such analysis - which focuses on ideational variables only at the level of the international community - misses the potential to analyse states as aligning their actions to their own varying national identity, that is, their undertaking actions to maintain ontological security. As with most studies on this topic, the implicit importance of these variables is nevertheless apparent in Fravel's work. When discussing frontier disputes, Fravel notes the importance for the PRC of the consolidation of "the territorial integrity of an "empire state" that continued the ethnic geography of previous dynasties' (Fravel, 2008, p. 44). However, despite this acknowledgement, the importance of the maintenance of authority in Tibet through territorial settlement is seen in fundamentally realist terms; the repression of Tibetan rebels aided by neighbouring states is important because of the strategic importance of Tibet. Any potential for ideational questions provided for maritime disputes is not given, and therefore whether the differences that arise between the two types of dispute are related to ideas of identity cannot be assessed.

The continuous implicit importance of ideational variables in existing literature is readily identified. In Donnelly's critique of realist theory, discussions on identity within realist scholarship are identified as usually being 'done unwittingly... neo-classical realists do have theoretical space for identity, but few have pursued the issue systematically' (Donnelly, 2009, pp. 48-49). This awareness but lack of prioritisation of China's internal national identity, as it relates to borderlands and the ethnic minorities that populate them, is commonplace in studies of China's borderland behaviour in its territorial disputes. For example, Hyer recognises central China's interaction with minorities as a key theme in the historical manifestation of China adopted by the Communist government, which act as a key determinant for where 
disputes arose. However, Hyer views ethnic minorities as an impediment to behaviour taking place within the international systems, stating (Hyer, 1990):

The obsession with the historical dimensions of China and contemporary security concerns have combined to make the resolution of long standing boundary conflicts difficult, unless international systemic factors make it necessary for China to make territorial compromises in order to ensure more vital national interests (p. 77).

Similar comments can be found in virtually all other authors discussing China's territorial disputes. Garver notes in different studies that 'China's campaigns in the South China Sea have been...inspired by a sense of destiny spanning centuries' (1992, p. 1028), and that Chinese sovereignty in the Sino-Indian dispute was 'vested conceptually in the people' (2011, p. 103). Nie's analysis concedes that 'ideological positions might, under certain circumstances, have an impact on China's handling of border disputes, [but] they are by no means the only explanatory factor' (Nie, 2009, p. 489). Nationalism and zealous irredentist claims regarding the historical conception of borders is also a notable argumentative approach, from which Maxwell (1999) maintains that the lack of progress in the Sino-Indian dispute was the result of the clash of these variables between the two disputant states.

These aspects of identity and history have been approached by constructivist scholars. However, while demonstrating the relevance of these variables more substantially, these works are limited in their application across the full scope of China's disputes. For example, reflecting criticism of alternative approaches use of identity, history and nationalism for coercive diplomacy discussed above, Suzuki (2014, p. 24) notes that such approaches trivialise the socialisation of historical interstate interaction into identity, as well as the subsequent impact of this on state interests. Offering a more nuanced approach, Suzuki (2014, pp. 34-36) argues that Chinese national identity has been formed through its interactions with external states acting as 'Others' to the Chinese 'Self'. Focusing principally on the Sino-Japanese relationship, this identity draws on Japan's historical occupation of China, informing China's identification as a victim of imperialism, and allowing a narrative of unique moralism to arise. Similarly, and in an argument reflecting that provided below, Gustafsson (2014) employs the ontological security approach to demonstrate how internal Chinese education has moved to secure contemporary Chinese identification as a 'victim' through patriotic education when it has been challenged by revisionist Japanese 
interpretations of the occupation of China. Although these scholars demonstrate the importance of interstate relations in forming ideational narrative recognised as pertinent to Chinese disputes, the subsequent implications of this to direct interstate behaviour is not clear.

Concepts of Chinese national identity have been applied directly to territory disputes. However, while supporting the importance of concepts posited by this thesis, these studies are limited to observations of Chinese identities in relation to a single external state. For example, in an argument closely reflecting this thesis, Guang (2006) argues that the 1962 border war occurred following Indian threats to China's identity as an emerging sovereign nation, particularly relating to the status of Tibet within it. However, in being limited to causes of conflict, Guang's argument cannot explain the Chinese pursuit of settlement on the border in 1960, the delayed initiation of this negotiation following the establishment of the PRC, or the move to cooperative behaviour on the border at a time when national identity relative to Tibet was under threat in the late twentieth century. Instead, this thesis argues that such an approach is overly simplistic, and that the security (or insecurity) of China's identity as a sovereign nation in fact impacted Chinese behaviour throughout the dispute, including its maintenance; subsequent moves to settle the borders; and the resulting conflict in 1962.

General differences in theoretical approaches aside, the primary significance of this thesis to International Relations scholarship is therefore in its expansion of existing approaches to China's behaviour in territory disputes, by looking Chinese identity as a central determinant across a variety of disputes. Rather than viewing the interactions of central China's ontological relationship with populated and uninhabited borderlands as a sideshow to higher matters of Chinese foreign policy (as with realist scholarship), or by focusing on the interaction of China's national identity relative to a single external state, this paper argues that the presence of minorities perceived as Chinese is a determining variable across Chinese border behaviour. In short, border settlement is argued to occur when China perceives that the settlement, or the actions of the disputant country, helps to legitimise China's incorporation of a wider population into the Chinese state. It is in this regard also that this paper most significantly diverges from existing comparative studies of maritime and frontier disputes. Rather than maritime disputes being seen as a delayed pursuit for unrealised resources, the absence of a local population sees China's approach become dependent on China's 
ontological relationship with the external state. Detailed support for this argument is provided below. 


\section{$V$ Chinese National Identity in its Territorial Disputes}

In his analysis of the PRC's shelling of Jinmen Island in 1958 - part of the ongoing desire of the PRC to 'liberate' Taiwan - Chen (2001) identifies several ideological points as the predominant factors in the Chinese motivation for the attack. The first relates to the need to unify and 'mobilise' the Chinese people leading up to the 'Great Leap forward', allowing the Chinese people to move on to the next socioeconomic level in their move towards a communist society. The second aspect of Chinese ideology in the Jinmen shelling is international, and relates to the need for the Chinese to challenge American interference in China's affairs. That this was more ideological than material, is supported by the rhetoric of Mao and other Chinese leaders, which placed the unity of the Chinese people, expressed as 'Tianxia' (all under heaven), above China's physical security through potential reprisal (2001, "Dancing" with Moscow, para. 5). Thus, Chen's analysis highlights two aspects of Chinese national identity, which can each be applied as the predominate determinant in China's frontier and maritime disputes. These relate to China's domestic understanding of the unity of the Chinese people, and the influence of China within Asia internationally.

This chapter will outline the history of Chinese national identity under the PRC. This first section will explore the key concepts of Chinese national identity as they relate to China's disputes, referring specifically to the significance of unity among the Chinese people, the 'Century of Humiliation', and 'Chinese exceptionalism'. The chapter will go on to argue that, broadly speaking, the development of these concepts can account for the lack of acknowledgement of border issues by the PRC prior to the late 1950s, and the subsequent cooperation in these disputes during the 1960s, and the late 1980s and 1990s. As will become clear, the concepts of Chinese national identity discussed here are closely interrelated. However, while the unification of the various peoples of China is central to frontier disputes, it cannot be applied to the uninhabited islands of the South China Sea, resulting in a divergence of Chinese behaviour across the two types of dispute.

\section{A Chinese National Identity: Exceptionalism, Humiliation and Unity.}

'Chinese exceptionalism', as identified by Zhang, has been manifest in Chinese ideology and foreign policy throughout Chinese history, during which it can be identified in various but interrelated iterations. The central theme of this ideology can broadly be found in imperial 
China, and is fundamentally related to the tributary system discussed above, in which (Zhang, 2011):

The Chinese perceived, and more frequently, presented Zhongguo (China, literally 'the Central State') as the centre of the known world, and superior to other polities culturally, morally, and materially... China would include other polities in its foreign policy domain and promote their development and prosperity under the influence and constraints of Chinese civilisation (p. 308).

China thus presented and understood itself as a great power which, in line with the ideologies of the tianxia, would draw its neighbours into its cultural sphere for their own wellbeing. The prosperity provided by such an ideology existed within a hierarchy which required other nations to exist within their proper place relative to the Zhongguo. For the PRC, the inheritance of this ideology was intermingled with both the communist ideological framework of the CCP and the historical legacy of China's suffering under imperial powers during the 'Century of Humiliation.' Despite the limited material strength of the PRC, 'in many ways, Mao and his comrades still regarded China as a 'special country' in the world, and they sought to re-establish China's central, if not dominant, position in world affairs' (Zhang, 2011, p. 309). China in the mid-1950s, therefore, still identified itself as the 'Central Kingdom', morally superior to other states, even whilst attempting to distance itself from the ideology of the Imperial Empire.

As noted, the great-power entitlement and moral superiority adhered to by the PRC was driven by the Century of Humiliation. The Century of Humiliation is possibly the predominant historical narrative of the modern Chinese state, and in keeping with Steele's ontological security theory, represents the main biographical narrative through which Chinese identity is understood. It represents the period beginning with the British and the Opium wars of the 1840s and traces the history of subjugation of the Chinese people to foreign powers and the loss of territory through unequal treaties, some of which are the subject of this paper. Upon the success of the 1949 revolution, Mao declared that 'Ours will no longer be a nation subject to insult and humiliation' and the cleansing of humiliation became a goal of China's foreign policy (Callahan, 2004, pp. 202-203). Far from representing a self-defeating victimhood, the concept of national humiliation provides the context through which the reascension to China's moral and material great power status can be achieved. As Callahan 
explains, 'the narrative of national salvation depends upon national humiliation; the narrative of national security depends on national insecurity' (Callahan, 2004, p. 203). The transformation of China was central to the goals of the CCP's revolution. Chen's analysis of Mao's ideological stance, dominant in the PRC's early years, was to 'transform China's state, population, and society, simultaneously reasserting China's central position in the world' (Chen, 2001, Ideology Matters, para. 6).

The Century of Humiliation has been used at different times to express Chinese national identity both outwardly, informing the international community of China's position in world affairs, and internally, emphasising the importance of solidarity in the Chinese nation. During the revolutionary period of the PRC, prior to Deng Xiaoping's reform period in the 1980s, the Century of Humiliation pervaded Chinese rhetoric regarding interstate relations. Domestically, this period saw the expression of the Chinese nation as united through socialist ideologies and class struggle, although it was implicit that the successes of these would in turn move China away from humiliation. Later in the late twentieth century, when Chinese power was assumed to be a matter of fact, the concept of Chinese national humiliation itself was also redirected inwards, replacing socialist and communist ideologies as the unifying characteristic of the Chinese nation. Infused with anti-foreign rhetoric, and enshrined in official maps, textbooks, and national holidays, national humiliation was employed proactively as propaganda, for the purpose of enhancing domestic Chinese nationalism (Callahan, 2009).

Despite the changing focus of the Century of Humiliation, the unification of the Chinese people has also remained a narrative of significance for the modern Chinese state, in which China is perceived as a 'unitary multi-national state created jointly by the people of all its nationalities', expressed in China as douyuan ti (Callahan, 2009, p. 136). The relationship between the Han and China's national minorities (the latter located along the frontiers of the Chinese state), formed a central aspect of the CCP's ideology both prior to, and following, 1949. The PRC sought to diverge from imperial and Republican Chinese representations of minorities as people to be excluded or subjugated, seeking to incorporate the frontier people into the Chinese state (Callahan, 2009, p. 128). Prior to the establishment of the PRC, CCP policy during the 1930s stated that upon the success of the revolution, minorities would have the option to secede from the Chinese state. Upon the founding of the PRC in 1949, the policy had changed to one of autonomy for national minorities within the unified Chinese 
state, in which autonomous national minorities would act to strengthen the territorial integrity of China, rather than to secede and detract from it (Callahan, 2009, p. 137). From the late 1950s, the initiation and subsequent failure of the Great Leap Forward, the continued legitimacy of the PRC and the continuous revolution, and particularly Mao's authority over it, would see an alignment of foreign policy with themes of Chinese unification and nationalism. Indeed, the history of the PRC during the twentieth century ultimately saw the notion of national unity had become so central to the elevation of China as a great-power that 'fragmentation constitutes one of the worst crimes left in China; the worst epithet is not capitalist or counterrevolutionary, but splittist' (Callahan, 2004, p. 209).

It is in this context that the characterisation of territory disputes as unfair and unequal can be understood. The management of the disputes by the PRC acts to legitimise the authority of the PRC, as well as by affirming Chinese exceptionalism and the rise of China out of national humiliation. While, like Fravel, it is tempting to view Chinese nationalism as likely to demonstrate a stubborn, aggressive and irredentist China intent on reclaiming the past territorial glory of the Qing, this is overly simplistic. Instead, in relation to the theory of ontological security, the changing pertinence of the above ontologies aligns with behavioural changes which are undertaken in an effort to provide ontological security. Thus, Chinese identity can be served by territory disputes through concession which aligns with China's perceived moral superiority over external states, and the legitimisation of the incorporation of minorities which assists in the unity of the Chinese people. Likewise, China's view of itself as the Central State can be secured through the influence or coercion of states internationally. Trends in the significance of these ontologies can be identified throughout the history of the PRC and applied to China's disputes with its neighbours. During this history, the emphasis on China as an exceptional state amongst the international community can be viewed adjacent to activity relating to China's maritime disputes; while periods in which the domestic integrity of the Chinese population becomes central to Chinese goals can be viewed adjacent to periods of activity in China's frontier disputes. Both of these types of activity can further be incorporated into the biographical narrative of China's accession, and later protection from, national humiliation.

\section{B The 1950s, Chinese Exceptionalism and National Humiliation}

The 1950s represents a period of ontological insecurity for China in relation to its place within the international environment. This insecurity was manifest in the PRC's 
preoccupation with its external relations, and an unrelenting desire to be viewed as a significant and superior state, and as the centre of international communism. In the first half of the decade, China's relations with the Soviet Union remained intact, yet China remained subordinate to the Soviets and on the periphery of international affairs more generally. Nevertheless, Zhang (2011) characterises Chinese exceptionalism in the 1950s as exhibiting what he describes as 'revolutionary sinocentrism', 'great power entitlement' and 'moralism'. Consequently, 'Mao and his comrades were first concerned with gaining China's great power status and restoring its autonomy that had been lost in the previous century...this was all informed by the wrenching contrast between China's past greatness and its recent suffering, as well as a profound sense of China's historical destiny as a great power' (Zhang, 2011, p. $315)$.

The 1950s saw Chinese foreign policy predominantly concerned with taking advantage of international events to align its perceived identity as a morally superior great power with its interactions and recognitions from other states. Chinese involvement in Korea was, therefore, articulated as the 'movement to resist America', and the focus of the movement was the creation of a powerful new China (Chen, 2001, The Alliance and China's Korean War Experience, para. 14). The ultimate holding of the American and United Nations Forces to the $38^{\text {th }}$ parallel was claimed as a victory by the PRC. The Chinese further utilised peace talks in Geneva in 1954, at the end of the First Indochina War, to influence great powers including France and Britain. As noted above, the shelling of Jinmen in 1958 can also fit into this pursuit of Chinese exceptionalism. During the crises in 1956 in Poland and Hungary, senior PRC officials provided a significant level of council to the Soviets on the proper use of military intervention in these fellow Socialist countries, and criticised the Soviets for what China perceived to be 'big-power chauvinism' (Chen, 2001, Liu Shaoqi and Deng Xiaoping in Moscow, para. 9).

Reference to Chinese territorial dispute was limited during the 1950s, but it will be recalled that Chinese activity in relation to its disputes during this period occurred most significantly in the reiteration of Chinese sovereignty over the island groups in the South China Sea. In line with the predominant Chinese ontology during this time, Chinese statements regarding infringement of China's sovereign rights make reference to shame and insult, conducive to the state of humiliation, which China was pursuing elevation from through its interstate behaviour. Thus, in its note to the South Vietnamese government concerning the alleged 
kidnapping of Chinese fishermen from the Paracels, the Chinese government accuses the Vietnamese of violating the 'sacred right of the Chinese people, which is absolutely not to be infringed on by anyone. But the South Vietnamese...want only to insult our national flag' (Amerkar \& Diverkar, 1964, pp. 216-217). This note goes on to demand that the South Vietnamese apologise for 'slighting the national flag'.

During this period, China had entered into a number of treaties of friendship with its borderland neighbours which, if not confirming China's place as a great power, enhanced China's standing within the region. This largely alleviated the need to pursue this status through the management of territorial disputes, explaining why China left these undefined throughout the 1950s, despite Indian and Burmese desires to discuss them. Furthermore, domestically the early 1950s was a time during which the PRC took a largely moderate approach to the incorporation of national minorities into the Chinese state. This period was envisioned as one of a gradual growing together of the Han and the minorities, in which the unity of the socialist Chinese state was to be undertaken 'in conformity with the wishes of the masses' (Dreyer, 1976, p. 94). While the CCP would undertake research missions into local minority populations, local officials were largely maintained and socialist ideology was promoted but not strictly enforced. If the settlement of territory disputes would ultimately be undertaken to reaffirm the unity of the Chinese, as argued here, there was little reason to undertake such a reaffirmation during this period. Instead, the above suggests a period of relative domestic ontological security for China in which moderate policies, while toned down from the right to secede of 1930s CCP policy, still acted to secure the self-perception that the PRC was diverging from the policies of Imperial and Nationalist China through which humiliation had occurred.

From 1956 the political landscape began to change both domestically and internationally, with events acting to provide security to China's identity as a globally significant power. The death of Stalin and efforts of de-Stalinisation undertaken by the Soviet Union allowed the PRC to present itself as a morally superior socialist nation. This, illustrated through China's self-assumed, ideological advisory role to the Soviets during the Polish and Hungarian crises, had resulted in a self-perception of 'Beijing's virtual centrality in world communism' (Chen, 2001, Liu Shaoqi and Deng Xiaoping in Moscow, para. 9). Indeed this self-perception of the PRC as a central state in international communism was inherent when the party stated that 'China's sovereignty had been restored' (Hyer, 1990, p. 40). This comment is made in 
relation to the PRC's territorial integrity, emphasising external relations and the Chinese State's position relative to them (Hyer, 1990):

Following the establishment of the People's Republic of China, the Chinese people have completely abolished the concessions, leased territories, and consular jurisdiction which the United States, Britain, and other imperialist countries acquired in old China, thereby ending the humiliating position of China as a semi-colony and restoring the states sovereignty and independence (p. 40).

Thus, in the late 1950s, the attention of the CCP moved to the internal mobilisation of the Chinese people in order for China to achieve to a higher socioeconomic level, causing a shift in ontology which subjugated the identities of national minorities under that of a unified, socialist Chinese people.

\section{The late 1950s, the 1960s, and the Domestic Mobilisation of Unified China.}

Increasingly, Mao and the PRC became preoccupied with the mobilisation of the Chinese people in order to facilitate the 'Great Leap Forward' - Mao's ambitious attempt to advance the Chinese socialist state through economic and industrial expansion. From 1958 situations such as the Taiwan crisis were actively engaged, as it was believed by Chinese leaders that such international situations could 'mobilise the population, could particularly mobilise the backward people, could mobilise the people in the middle, and could therefore promote the Great Leap Forward in economic construction' (Chen, 2001, From Tension to Crisis, para. 15). Undoubtedly Mao's reference to the 'backward' and 'middle' people was towards national minorities of the frontier. The need for and emphasis of national unification can be identified in changes to the central government's policies towards these people. The formerly moderate policy of respect for special differences in ethnic minorities was replaced with a change in the perception of the role minorities would play in China's progress. '[For the Great Leap to succeed] clearly such an ambitious program required unity. Diversity became the antithesis of unity, ethnic diversity came to be regarded as a hindrance to the achievement of the Great Leap's goals' (Dreyer, 1976, p. 159).

Eventually the pursuit of unity by the PRC under Mao would reach its zenith in the Cultural Revolution beginning in 1966, and representing the most assimilative period in the history of the PRC. During the Cultural Revolution the previous policy, of gradual progress and 
unification of national minorities, coupled with the recognition of their differences, was replaced with a strict ideological emphasis on class struggle, in which 'the idea that the various nationalities should follow their own culture became a casualty' (Mackerras, 1994, pp. 150-153). Nevertheless by the beginning of the Cultural Revolution many of China's territorial disputes had been resolved. It was in the years between the initiation of the Great Leap Forward and the Cultural Revolution that the majority of China's territorial disputes were settled, or, in the case of India, that settlement was offered. These years (1958-1965) mark a period in the history of the PRC in which ontological security was pursued in part through re-routinizing China's interactions with the states on its borders. Chinese unification became central to the biographical narrative of the PRC, with a unified socialist nation coming to be seen as analogous to the advancement of the Chinese state particularly following the Tibetan Revolt of 1959 (discussed below). During the period prior to the Cultural Revolution, the party still sought to incorporate minorities without wishing to assimilate them fully. In China's frontier regions, where historical and contemporary interstate influence potentially imparted ambiguous influences on minority populations, the settlement of territorial disputes allowed the Chinese to reaffirm the explicit Chinese sovereignty over those minorities, providing external recognition of, and therefore security for, this aspect of China's ontology. This is discussed in more detail relative to the Indian and Burmese border disputes below. However it is finally worth noting that issues relating to China's frontier border disputes would not be raised again until the 1980s, after the extreme nationalities policy of the Cultural Revolution had begun to be removed by the PRC leadership (Mackerras, 1994, pp. 153-154), and in which new Chinese and minority nationalisms had begun to arise.

\section{The Burmese Settlement}

I have argued above that China's settlement of territory disputes can be seen to align with periods in which the ontology of a united China was central to Chinese goals. However, the question remains as to how the Burmese settlement and the ongoing relations with India provided security for this aspect of Chinese identity. The Burmese settlement can be seen to provide a manner of ontological security for the Chinese in a number of ways, at least in its allusions to the Century of Humiliation through references to the illegitimate origins of the disputed border. It will be recalled that the Burmese had acknowledged that the border had been a product of foreign imperial politics of aggression (Watson, 1966, pp. 128-130). Furthermore the agreement was made with continued reference to the 'Five Principles'. By 
recognising the Chinese victimhood at the hands of imperial powers and by cooperating in negotiations allowing the PRC to remedy this status in line with the high morals of the 'Five Principles', the Burmese settlement confirmed for China both its moralistic superiority in interstate relations as well as its ascension from the Century of Humiliation. However the Century of Humiliation cannot be seen as the primary ontology being secured here, as settlement could have occurred for this purpose from the mid-1950s when Burma first approached China on the issue.

Here, allusions to the Century of Humiliation should therefore be understood as situating this settlement within the narrative of advancement away from humiliation. The timing within the period of insecurity of Chinese unity sees this settlement act to reaffirm the Chinese nationality of the borderland people, and to prevent and control cross-border interaction between the minorities of Northern Burma and the Chinese frontier lands. Most explicitly, this occurred through clarification of tribal groups as coming under Chinese control - the socalled 'administrative clarification' of the jurisdiction of villages and tribes along the boundary line. Where Chinese concession occurred in the provision of the Nanwan Tract to the Burmese, it was made explicit that this was in exchange for sovereignty over tribes for which China had historical ties. This indicates that the inclusion of tribal groups perceived as Chinese was of greater importance than territorial possession. In addition to comments on the undertaking of the settlement, the clarification of sovereignty over local tribes formed the majority of joint press communiqués issued following the settlement of the border (Amerkar \& Diverkar, 1964, pp. 188-204).

Additional evidence of this can be found in points presented in a note from Premier Chou Enlai to the Burmese Prime Minister, $\mathrm{U} \mathrm{Nu}$, in October 1960. The note is solely presented for the purpose of clarifying points related to the borderland peoples. Reiterating the purpose of the delimitation of tribes outlined in the border agreement, Chou writes that 'the inhabitants of the areas to be handed over by one side to the other... shall, after handing over the areas, be definitely considered citizens of the side to which the areas belong' (Amerkar \& Diverkar, 1964, p. 202). The definitive nature of this agreement was to follow a grace period in which the inhabitant could 'declare their choice of nationality', presumably meaning Chinese rather than the local national minority more likely to apply to the person in question. The note continues in outlining principles for the limiting of interaction between the border inhabitants (Amerkar \& Diverkar, 1964): 
In accordance with the principle of mutual respect for sovereignty and territorial integrity, and in order to facilitate administration by each side and to avoid disputes between the border inhabitants...the two sides are of the agreed opinion that the question of cross border cultivation of trans-border lands, which exists now in the Sino-Burmese border area...should be settled...Each side shall see to it that no new cases of transfrontier cultivation shall be allowed by its inhabitants (p. 202).

Following the border agreement, what was once a border over which certain minority peoples populated both sides, was now "'not so vulnerable to outside penetration" as they once had been' (Mackerras, 1994, p. 190). While it is tempting to view this determination as the clarification of normal territorial principles, it should be recalled that until 1960 the PRC had been content to manage the border through the presence of the People's Liberation Army, despite the claims to the Five Principles of Peaceful Coexistence. Had China simply desired to clarify its territorial boundaries and their associated jurisdictions, why had China not undertaken settlement with Burma earlier in the 1950s following Burmese approaches to China regarding such settlement? It is more likely that this principle acted as a symbolic gesture, not only between the Burmese and the Chinese, but also to the Chinese people, signifying that those within the Chinese borders were an inalienable part of the unified Chinese nation. U Nu's reply to the note, in which Chou's note was reproduced in full before being confirmed on all points on behalf of the Government of Burma, was published in periodicals, meaning its existence was not kept to only the local level which the note concerns.

The reaffirmation of the South Eastern minorities as part of the Chinese state in 1960 can be seen as arising for a number of reasons. The connections between these groups of minorities, particularly those in the Yunnan province bordering Burma, were those with which the CCP had the weakest connections prior to 1949. In the period of 1956-57, as part of the CCP's research into local minority groups, the Yunnan people were further characterised as unwilling to progress the local minorities further towards socialist development despite the undertaking of democratic reforms and autonomous status in the region (Dreyer, 1976, pp. 147-152). As discussed above, the progress towards a unified socialist society was central to the PRC's domestic polices from 1958. The Burmese settlement therefore allowed the Chinese an opportunity to declare the indisputable Chinese nationality of the people within 
the Burmese frontier and to have this confirmed by the nation from which potential conflicts of influence and identity had existed. The Chinese did not make this gesture until the time when the understanding of a unified Chinese people and their mobilisation was critical to the state's central ontology. Likewise the concession of disputed land was possible both because territorial gain was not the desired outcome of the agreement, and because providing such a concession reaffirmed China's perceived exceptional moral nature.

\section{India, Tibet, and the Dalai Lama: Concession and Conflict}

In the case of Tibet, the Chinese had been making explicit pronouncements of Chinese sovereignty over the Tibetan people long before the attempt at settling the dispute occurred, and the sparse nature of the frontier meant that 'clarification' of Chinese sovereignty over certain tribal groups could not be expressed as with Burma. Unlike the Chinese interaction with Burma, where internal transformations to China's ontology caused a need to change its interactions with Burma to provide security, the Indian settlement arose from both these internal ontological changes, as well as what China saw as India's facilitation of the major threat to the unified China ontology represented by the Tibetan separatist movement. China therefore moved to realign its interactions with India by formalising the border as the boundary of the Chinese state thereby providing security for the inclusion of Tibet within China through recognition of this from India. Despite opportunities to settle the dispute earlier, the offer to settle did not occur until the threat to China's ontology had manifested. In January 1959, prior to the rebellion in Tibet, the Chinese government responded to Indian protests against maps including parts of the disputed territory with no move towards seeking settlement, and instead suggested the status quo be maintained as changes would 'give rise to confusion among our people' (Amerkar \& Diverkar, 1964, p. 118). Given the construction of the Chinese road in the area, the Indian protests had sought clarification from the Chinese of their claim to the Aksai Chin. That the Chinese did not pursue settlement at this point, illustrates that the timing and significance of the Chinese offer in 1960 was not motivated primarily by maintaining the security of this strategic interest.

The Tibetan revolt in Lhasa in March 1959 represented for the PRC one of the most significant threats to national unity it had experienced. Tibetan rebels were accused of 'betraying the motherland and the people and undermining the national unity' (Smith Jr., 2009, p. 53). More broadly, Tibet in general was subsequently perceived to have 'not accepted the socialist road as the inevitable trend of the development of history and the 
common desire of the people of all nationalities' (Smith Jr., 2009, p. 52). Following the Dalai Lama's escape to India, 'democratic reforms' were initiated by the CCP in order to strengthen Tibet's place within the Chinese socialist state. However, the ontological integrity of Tibet as Chinese remained under threat when, despite assurances to the contrary by the Indian government, the Dalai Lama was able to make repeated political criticism of Chinese rule in Tibet from his sanctuary in India. While India had previously affirmed its recognition of Tibet as Chinese, its unwillingness to denounce the Dalai Lama and its criticism of Chinese actions in Tibet drew harsh criticism from the Chinese government (Mackerras, 1994, p. 180), and disrupted the Sino-Indian relationship which had held India recognition of a Chinese Tibet as routine.

This threat to Chinese unity and its connection with the Sino-Indian border can be seen in communications between India and China in September 1959. As of the $8^{\text {th }}$ of September, a letter from Chou En-Lai continued to allude to the Century of Humiliation. Referencing British attempts to create an independent Tibet in the eighteenth century, Chou cited that were the Chinese to accept the 'illegal' McMahon Line, itself a 'product of the British Policy of aggression', China would 'disgrace itself' (Amerkar \& Diverkar, 1964, p. 126). Yet at this time, still no suggestion of settlement or concession was made. This changed abruptly in the following days. On the $9^{\text {th }}$ of September 1959, having been given assent by Nehru, the Dalai Lama's challenges to Chinese rule in Tibet reached their zenith when he approached the United Nations requesting intervention on the Tibetan issue (Mackerras, 1994, p. 180). In this, the Dalai Lama directly challenged the right of the Chinese to sovereignty over the Tibetan people, stating that 'no power of authority was exercised by the Government of China in or over Tibet since the Declaration of Independence by the $13^{\text {th }}$ Dalai Lama in 1912' (Amerkar \& Diverkar, 1964, p. 456). Only two days later, the Chinese People's Congress internally determined their position on the territory dispute for the first time, articulating what would eventually be offered in the 'package' deal to India in April of the following year, including the acceptance of the border along the illegal McMahon Line (Hyer, 1990, pp. 131132).

From that time Chinese pursuit of negotiations with India began. In the Chinese government's response to the United Nations, it is clear that the Chinese viewed the Dalai Lama's approach to the international community as a threat, not only to their position in Tibet, but to the ontology of a united China. This response was issued the following month, 
stating that the Dalai Lama and the United Nations 'absolutely cannot affect the advance of the Chinese people of various nationalities, including the Tibetan people, united as one [emphasis added], on the road of prosperity and happiness' (Amerkar \& Diverkar, 1964, p. 463). Likewise from this point, Chinese communications with India on the border issue began to allude to negotiations towards settlement needing to take place in accordance with the expectations of the Chinese people. 'In language which strongly reflects that of Mao in his pursuit of national unity towards socialist progress, Chou's final letter to Nehru prior to the failed negotiations in 1960 notes the support that settlement could offer (Amerkar \& Diverkar, 1964):

Both of our countries are still very backward, economically and culturally. We urgently need to engross ourselves in long-term peaceful construction at home so as to free ourselves step by step from the present state of backwardness (p. 164).

Certainly as suggested by other authors, the Sino-Indian border issues in the late 1950s and early 1960s were tied explicitly to the matter of Chinese sovereignty over Tibet. Yet the important difference here is that these need to be understood with reference to the ontological security of the concept of a unified China, not due to the strategic importance of Tibet or the need for border security. It is for this reason that this offer of settlement occurred in conjunction with other offers of settlement, beginning late in 1959, at a time during which the unified China ontology was central to Chinese goals of socialist progression. Settlement of the border for material security could have occurred at any time during the first decade of the PRC. Equally, the offer to settle could have been undertaken during the months that followed the Tibetan revolt in Lhasa. Instead, the Chinese decision to settle with India and to concede disputed territory coincided with the Dalai Lama's most high profile challenge to the identity of a unified China. Thus, where this ontology was threatened externally, Chinese behaviour shifted to secure it. This was sought through the recognition of the authority of the PRC to determine Tibet's external border, as settlement with India would thus have acted to validate China's incorporation of Tibet into China by reaffirming the PRC's sovereignty over Tibet in the most formal and internationally legitimate sense.

China maintained its policy of settlement and concession along the McMahon Line throughout 1961, during the period in which Nehru undertook his 'Forward Policy' and progressively moved Indian forces towards and over the disputed boundary. What ultimately 
caused China's determination was Chinese perception that India's claim to the strategically important Aksai Chin was occurring in conjunction with Indian collusion with the United States Central Intelligence Agency 'to weaken and undermine China's rule in Tibet' (Garver J. W., 2004, p. 10). Thus, it was only once the integrity of the Tibetan people as Chinese subjects was perceived as being under direct threat from India, and not the threat to the border itself, that China determined to use force against India in October 1962. This theory is supported by the subsequent withdrawal of Chinese forces away from the border at the height of China's success in the war, from which they moved back towards calling for negotiation.

Following the war and the breakdown of diplomatic relations between India and China, with India's policy of no concessions unchanging, the possibility of attaining ontological security in Tibet through settlement of the border was no longer achievable for China. Nevertheless, this same goal was subsequently pursued by the Chinese via alternative means. In 1965 the Tibetan Autonomous Region (TAR) was officially established. The interaction of the border dispute with Tibet's incorporation into the socialist Chinese state, and the centrality of this to progress in the state, are illustrated at this time in an article in the People's Daily. In this article, the rhetoric regarding the border war was being used to affirm the unification of the Tibetan people who had 'joined the Han people and the peoples of other nationalities to wage an unflinching fight [against the Indians]'. In turn, this had led Tibet to 'safeguard the unification of the motherland', while in Tibet the 'economy, with its socialist and semisocialist character is gaining progress' (Hinton, 1980, pp. 834-835). The establishment of the TAR occurred as an opportunity to further repeat the denunciation of the Dalai Lama, and signalled the CCP's 'desire to secularize the Tibetan administration' along with the full incorporation of Tibet into the state's provincial system (Dreyer, 1976, p. 201). The leadership of the Tibetan government, which had previously been filled by the Dalai Lama, was replaced by a secular leader. This, in turn, was followed by the more extreme assimilation policies of the Cultural Revolution, during which time the Sino-Indian border remained unaddressed.

\section{The 1970s: The Central Kingdom in the South China Sea}

According to Chen, in the late 1960s and following into the early 1970s, sino-centrism and great power entitlement played a central role in Chinese relations with its South-East Asian neighbours. Chen (2001) argues that the deterioration of Sino-Vietnamese relations during the Vietnam War occurred as North Vietnam refused to recognise the superiority of China 
amongst Asian nations. Thus Beijing's decision to withdraw support from the North Vietnamese is seen as a consequence of the North Vietnamese decision to negotiate with the United States despite advice from the Chinese communists to the contrary, and the offence this caused to Chinese perceptions of itself and its rightful place in Asia. This pattern extends beyond Sino-North Vietnamese relations, with Chen noting that (2001):

\begin{abstract}
From a historical-cultural perspective, Beijing's seemingly revolutionary and idealistic policy towards Vietnam ironically had been penetrated by an age-old Chinese ethnocentrism and universalism. While Beijing's leaders and Mao in particular, emphasised repeatedly that the Vietnamese should be treated as "equals," the statement itself revealed the Chinese revolutionaries' strong sense of superiority... Beijing asked for something bigger, that is, the Vietnamese recognition of China's morally superior position. In other words, what Beijing intended to create was a modern version of the relationship between the Central Kingdom and its subordinate neighbours [emphasis added]. (The Failure of an "Alliance between Brotherly Comrades", para. 5)
\end{abstract}

Thus the actions of South East Asian states such as North Vietnam caused insecurity to the 'Central State' ontology, within which peripheral states were expected to show deference to Chinese moral and material authority. This sense of superiority was magnified in the early 1970s by China's inclusion in the United Nations, and China's rapprochement with the United States. It is within this context of Chinese superiority over its neighbours, particularly those of South East Asia, that Chinese aggression and the use of force in the 1974 Battle of the Paracels can be understood. That is, this change in Chinese behaviour can be viewed as an attempt to secure this ontology through its forced recognition by peripheral states, returning South China Sea interactions back to those in which Chinese authority was implicit.

Indeed, China's actions during the conflict suggest an expectation that South Vietnamese forces would submit to China without conflict, reflecting the innate subordinate nature China understood its South-East Asian neighbours to hold in relation to the 'Central Kingdom'. China's initial expansion into the Paracel Island chain was undertaken by Chinese fishing vessels, without People's Liberation Army (Navy) (PLA(N)) vessels operating in the area. The Chinese strategy relied on a belief that they could 'persuade Vietnam' to accept the Chinese presence in the island group. Subsequently, Chinese forces were instructed to engage in a 'struggle of persuasion' through which Vietnam would come to accept the Chinese claim 
(Fravel, 2008, pp. 281-282). It was not until South Vietnamese forces engaged the Chinese that the Chinese reciprocated with force, and then captured additional islands following the defeat of the Vietnamese forces. That China's expectation was that its expansion in the Island Group would be accepted through persuasion, and that the failure of this resulted in force, is reflective of the Chinese ontology of China as the Zhongguo in relation to nations on its periphery. This is further reflected in a Chinese statement on the conflict, in which the Chinese action is seen to 'contain...the hegemonism... of South Vietnam and our country's peripheral nations' (Fravel, 2008, p. 286).

\section{E The 1980s and 1990s: The Reform Age and the turn in Chinese Exceptionalism}

In 1978, following the death of Mao and the end of the Cultural Revolution, the revolutionary period of the PRC gave way to domestic and international rationalisation under the leadership of Deng Xiaoping. As discussed in the sections below, this resulted in a new articulation of Chinese nationalism and movement for national unity, as well as changes in the nature of China's foreign policy. Again, these changes correspond with identified transformations in Chinese national identity. This period sees a continuation of Chinese exceptionalism, but one which is prefaced in the assumption of China's Great-Power status, not the pursuit of such a status. Working from this point, Chinese exceptionalism becomes typified by references to China's unique culture, one founded in Imperial China, which sees China diverge from typical behaviours of other great powers. Thus Chinese ideology begins to stress that 'it will always adopt a peaceful foreign policy, will never threaten anyone, and will help to maintain peace through its own development' (Zhang, 2011, p. 311). Furthermore, the emerging principle of 'harmony with difference' 'can be represented as the principle that countries should conduct harmonious relations with each other while maintaining differences in views' (Zhang, 2011, p. 313).

Beginning in the 1980s, changes in Chinese rhetoric regarding territorial disputes is reflective of this change. This rhetoric was first relaxed, and from 1988 China entered a period marked by an increased willingness to address territorial issues through international agreements and confidence building measures (Carlson, 2010). However this change in approach moved only to rearticulate the status quo in these disputes, rather than a move towards settlement realisation. Concepts of national unity and the tianxia remained pertinent to these disputes, although these concepts now became incorporated into Chinese identity in a way which saw them also affirm China's unique, superior and peaceful nature. Thus the uniquely peaceful 
nature of the Chinese state is achieved through an 'assimilation and integration of different peoples and cultures' unachievable by the west (Zhang, 2011, pp. 311-313). External peace is seen as achievable through the incorporation of South East Asia into the tianxia, with the 'Central State' now offering the model of peaceful and cooperative behaviour (Zhang, 2011, pp. 311-313). Below, these changes to Chinese national identity are applied to the occasional tension, and the emergence of cooperative behaviour in the Sino-Indian border dispute and the South China Sea disputes during the 1980s and 1990s.

\section{The Sino-Indian Dispute and Defining the Chinese Nation}

Sino-Indian cooperation regarding territory disputes leading to the recognition of, and agreement to accept, the line of actual control came on the back of two significant events; the uprisings and unrest in Tibet at the end of the 1980s, and the 1989 Tiananmen Square demonstrations. During the early 1980s, Chinese policy in Tibet had liberalised and allowed for greater autonomy within the Tibetan region, as well as the recognition and practice of Tibetan culture and Buddhist religion (Mackerras, 1994, p. 154). Increased integration of Tibet into the Chinese state had therefore moved away from the strict assimilation policies of the past decades, and was now pursued through increased economic integration of the region with central China (Smith Jr., 2009, p. 166). During this time it was generally felt that improved conditions were successfully facilitating integration of Tibet into China, a perception which provided a state of relative security of the situation of Tibet within the unified China ontology. Thus, while border talks were occurring between China and India in the context of improving Sino-Indian relations, it will be recalled that no meaningful progress was made on the issue, with no formal agreements sought by either side.

That the liberalisation policy in Tibet resulted in an increase in Tibetan nationalism, resulting in increased demonstrations from separatists, evidently took Chinese elites by surprise, thus disrupting the narrative that Tibet was increasingly integrating into the Chinese nation. Beginning in September 1987, Tibetan nationalists began a series of marches through Lhasa calling for the separation of Tibet from China. Despite Chinese dispatches of PLA personnel to the region to undermine the demonstrations, they would continue until March 1989 (Mackerras, 1994, p. 161). Calls for Tibetan independence were amplified through the activities of the Dalai Lama and his 'government in exile' during this time. These actions were themselves amplified further through the condemnation of China and its actions in Tibet by Western countries, principally the United States. When the pro-democracy demonstrations 
in Tiananmen Square broke out in mid-1989, the ensuing crackdown by the Chinese government was internationally connected to the events in Tibet under the more general guise of human rights abuses by China (Mackerras, 1994, pp. 187-190). All this resulted in what was seen by the Chinese as the single most significant threat of split in the unified Chinese nation, and resulted first in the imposition of martial law throughout China. In effect, the ontological security achieved through the policies of the 1980s had been threatened both internally and externally. To re-secure this ontology, this threat was followed by a radical change in domestic policy away from the liberalisation of the 1980s, and towards a greater emphasis on nation unity and loyalty to the CCP (Smith Jr., 2009, p. 167). Externally, as in the 1960s, the integrity of Tibet within the Chinese nation was sought through the recognition of the limits of Chinese sovereignty as including the Tibetan region.

Following the demonstrations in 1989, in order to quell the domestic unrest which had led to the demonstrations the central government initiated work towards what would become the Patriotic Education Campaign, which sought to engender 'unified' and 'correct' thinking among the Chinese people. This education took the form of the official domestic promotion of the Century of Humiliation through education, official publications and textbooks. While the Century of Humiliation had frequently been used to understand China's situation within the international community, the mobilisation of the Chinese people had been expressed in terms of 'class struggle and revolutionary victory' (Callahan, 2009, p. 35). Now for the first time since before the 1930s, national humiliation became communicated as the very basis of the identity of the Chinese people, with the stated aims of patriotic education included to 'enhance national cohesion, foster national pride, [and] develop a patriotic and united front [emphasis added]' (Callahan, 2009, p. 35). Thus the biographical narrative of national humiliation was employed in the shifting of attention away from domestic political issues, instead focusing ideological perspectives back to the wrong doing of foreign powers. This reeducation of the Chinese people stressed to great lengths the distinction between the foreign and the domestic, and the growth of Chinese nationalism in the 1990s would go on to reinforce the distinction between those who were internal and loyal to China and the threats that existed externally. This continues to be communicated in rhetoric which stresses the defence of national borders which 'peacefully hold together millions and millions of families' (Callahan, 2009, p. 62). In other words, the borders within which the Chinese people exist in unison. From the mid-1990s, patriotic education would be employed in Tibet in particular, in 
order to transform the rise of Tibetan nationalism into a shared Chinese identity (Smith Jr., 2009, p. 170).

It is in this capacity that the 1993 agreement on the line of actual control can be seen as reinforcing the unified Chinese nation. During the 1990s, as part of the patriotic education regarding national humiliation, the Chinese government published a new wave of 'national humiliation' maps of the Chinese empire intended for domestic consumption, the first time such maps had been produced since the PRC's establishment. These maps are not unique publications, but rather officially sanctioned and popular representations of the Chinese state. In his detailed analysis of these maps, Callahan notes that in the context of China's 1990's nationalism, these maps are intriguing in that they act not as 'evidence of a loss of national territories... [but rather] how China has asserted national sovereignty over an ambiguous imperial domain, transforming the periphery into an integrated sovereign territory' (Callahan, 2009, p. 109). In other words, in the 1990s a clear understanding of the borders of China became integral to the concept of the unified Chinese nation, because they acted to show how the PRC had successfully incorporated areas of nominal sovereignty, including Tibet, into a unified and modern nation state. The agreement with India provided external recognition and security for this internal Chinese narrative.

Therefore, as with Chinese offers of settlement in 1960, what is important here is that the agreements with India in the 1990s allowed China to articulate the limits of its sovereignty, the line of actual control, within which the Chinese nation could be seen to exist. This further explains why agreements were not reached during the 1980s, as it was from 1989 that the pursuits of this identity became most pronounced. Thus, as with the events in 1960, the 1993 agreement took place at a time when this unity was under threat, and when the importance of national unity was perceived as central to the goals of the PRC. Whether settlement of the border took place or not was therefore not important, and in any case was still impeded by Indian resolve to not accept the Chinese package deal. Regardless, the Chinese authority to settle the border in due course was recognised by India in the agreement which stated that 'the two sides are of the view that the India-China boundary question shall be resolved through peaceful and friendly consultations', and that in accordance with the line of actual control, the principle of non-interference in internal affairs would be observed (Agreement on the Maintenance of Peace and Tranquility, 1993). This was also served through India's repeated recognition on Chinese sovereignty over Tibet. 


\section{Cooperation without Settlement in the South China Sea}

Chinese activities relating to its maritime territory claims in the South China Sea during this period resulted in conflict in 1988 and tension in 1994. This was followed by an extended period of cooperative behaviour during which China sought to normalise interstate relations within the region, without undermining its actual claims within the South China Sea. As noted above, the period up until 1988 represented a period of transition in Chinese territorial behaviour prior to cooperation occurring. This transition in the approach to territorial disputes is reflected in the 1988 conflict with Vietnam over Johnson Reef in the Spratly Island group. While the leaders in the central Chinese government progressed towards cooperative behaviour, in the PLA(N), naval doctrine throughout the 1980s continued to stress the 'lost territories' narrative (Buszynski, 2003, p. 346), typical of China's previous use of force in the area. Such a representation of the dispute was evidently pervasive in the PLA(N)'s justification for its activities in the area, such as the assertion from PLA(N) personnel that 'every time we... sail and patrol, we exercise sovereignty on behalf of the ancestral land [emphasis added]' (Garver J. W., 1992, p. 1009).

The PLA(N)'s doctrine was developed under the leadership of Admiral Liu Huaqing, whose leadership, not that of the central Government, would drive expansion of Chinese South China Sea holdings into the Spratly Island group (Fravel, 2008, p. 290). Therefore, despite the changes in Chinese national identity noted above, the 1988 Battle of Johnston Reef must be understood in the same context as that of the Battle of the Paracels; that being the lack of deference to the 'Central Kingdom' in conformity with its superiority over the peripheral South East Asian states. Indeed, while South East Asian states had been active in the region throughout the 1980s, and the 1988 clash only occurred following threats to the security of this ontology resulting from dismissive responses from the Vietnamese to Chinese calls for their activities to cease, seen as an apparent affront to Chinese authority in the region. Garver (2011, p. 1023), while arguing that this activity was pursued for economic reasons, seems to suggest that the modernisation of the navy and its actions in the Paracels was enabled in large part due to the appeal to this aspect of Chinese identity. The centrality of the 'lost territories' narrative to the $\operatorname{PLA}(\mathrm{N})$, and its divergence from alternative Chinese identity at the time, can further be used to explain the Chinese occupation of Mischief Reef in 1994, as this action likely occurred without the knowledge or approval of the central Chinese government (Fravel, 2008, p. 297). 
However the mid-1990s saw the influence of the PLA(N) wane (Buszynski, 2003). The years following the Mischief Reef occupation are notable for the initiation of Chinese behaviour which, in the negotiation and signing of the Declaration of Conduct with its emphasis on peaceful management of the dispute, is indicative of the influence of the emerging Chinese exceptionalism. As with the re-emergence of maps of National Humiliation relevant to China's national unity, as discussed above, these maps from the mid-1990s, depicted the 'hierarchical depiction of vassal states, semi-states, and frontier zones' of China, including its traditional sphere of influence over South East Asian states (Callahan, 2009, pp. 107-109). Rather than literal representations of lost territory, these instead are an articulation of the symbolic place of China in Asia. These maps can be understood in relation to the evolving ontology of Chinese exceptionalism, which saw China as a peaceful and harmonious state founded on unique cultural attributes inherent in the neo-tianxia. In this sense, China's cooperative behaviour in the South China Sea occurs at a time when ontological security, particularly in relation to South East Asian states, could be achieved through the manifestation of China as a power with inherent influence and leadership by way of peaceful cooperation and development.

This can be observed in the Chinese inclusions in the draft Declaration, which stressed the putting aside of disputes in favour of joint development and cooperation (Buszynski, 2003, p. 355). The relevant provision in the final text reiterates this, stating that negotiations were to continue 'for the purpose of promoting good neighbourliness and transparency, establishing harmony, mutual understanding and cooperation' (Declaration on the Conduct of Parties in the South China Sea, 2002). The shift in behaviour to reflect this new Chinese national identity is further reflected in appeals to China's harmonious and peaceful leadership in the South China Sea made by Chinese Premier, Jiang Zemin in 2002, around the time of the signing of the Declaration of Conduct in which he stated that (Jiang, 2012):

The Chinese nation has inherited from ancient times a fine tradition of honesty, harmony and good faith - values that China consistently abides by in the conduct of relations with other countries. The very purpose of China's foreign policy is to safeguard world peace and promote common development. 
In this discussion one aspect of Chinese behaviour appears to stand as an anomaly. It was noted that the PLA(N) was responsible for the aggressive behaviour of China in the region in the late 1980s and early 1990s, based on a national identification separate to that emerging in China more generally. But why then did the central Chinese government pass the law of 1992, challenging disputant states by designating the South China Sea as existing under the exclusive sovereignty of China? Buszynski (2003, p. 349) suggests that the turn in 1995 is representative of the shift of management of the dispute to the Ministry of Foreign Affairs, and the realisation that economic exploitation could better be served through multilateral cooperation. However an alternative explanation exists which is complementary of Chinese ontological security seeking as a morally superior and harmonious great-power. The significance of the Chinese exceptionalism of the 1990s emphasised uniquely harmonious behaviour. For China this uniqueness was found in the accommodation of states within the South China Sea despite the recognition of the region as being Chinese sovereign territory. Such sentiment has been noted by Carlson, much of which has risen from a 'frustration over the lack of international recognition of what is seen as Chinese restraint' (2010, p. 697). The formal articulation by China of the region existing as sovereign territory should therefore not be seen as aggressively challenging the claims of others, but in signifying the significance of Chinese restraint and accommodation in the South China Sea which followed. In this way the 1992 law becomes part of the biographical narrative of the South China Seas dispute, in which the extent of China's benevolence becomes understood through its situation relative to the formal identification of the territory as Chinese.

\section{F Continuing and Predicted Trends in Chinese Territory Disputes}

Since the periods of cooperation in the Sino-Indian and South China Sea disputes noted above, few events of equal significance have occurred. The question could be asked - what, if anything, can be said of the likely direction of these disputes? On China's Indian border, the settlement process remains stymied by Indian nationalism, which has consistently prevented offers of concessions in the eastern sector from the Chinese. Given the recognition of the line of actual control, and the unlikelihood of agreed formal settlement, interactions with India over the border now offers China limited ontological security beyond the status quo. Nevertheless what can be suggested with confidence is that China will not attempt to extend its borders through force, as predicted by some realist commentators. If it is taken that mutual recognition and reaffirmations of Chinese unity motivate settlement, then the forced extension of these boundaries offers little benefit to China. Where tension or even conflict 
occurs this is likely to be in defence of the status quo. Such actions and sentiment can be seen in the comments of the Chinese ambassador to India following tensions along the border in 2009 (Keep peace on China-India border, 2009), and in the 'resolution' of recent tensions in 2014 (Bedi, 2014). In lieu of changes to Indian policy, ostensible progress will continue to be represented in adherence to and recognition of the line of actual control, not an official border.

Alternatively, in China's disputes in the South China Sea, the return to aggressive behaviour which has occurred in recent years has followed a shift in Chinese national identity identified by Rozman (2011) as beginning in 2007. Rozman suggests that China's identity as a peaceful and harmonious Asian leader was threatened by the renewed emphasis on the Asia-Pacific region by the United States under the Obama administration. Regarding China's interactions with its South East Asian neighbours, this has resulted in 'repeated references to neighbouring countries failing to cooperate or showing a lack of respect' (Rozman, 2011, p. 85). Such analysis is reflective of China's earlier interactions within this dispute, in which ontological threats to China's position as the Zhongguo were responded to through aggressive assertion of Chinese authority. The shift and its situation within the ontological security argument is supported by China's recent aggressive behaviour towards disputant states. Thus, whether China's management of its South China Sea occurs in the guise of peaceful cooperation or aggressive posturing and conflict, is dependent on the changing selfperception of China's role as a harmonious regional power. Regardless, China is unlikely to offer concessions to disputant nations, and therefore these are unlikely to be settled peacefully. Unlike China's frontier disputes, the settlement of maritime disputes through Chinese concession offers little benefit to China, both materially and ideologically. 


\section{Conclusions}

Throughout the twentieth century and into the twenty-first, the construction of national borders for China has existed in a balance between concepts of 'unbounded imperial domain, and bounded sovereign territory' (Callahan, 2009, p. 94). In other words, the Chinese notion of national territory encompasses more than just its fixed boundaries but also the recognition of those within these boundaries as comprising a unified multi-national state, and those on the periphery recognising the superiority of the 'Central Kingdom'. Two concepts cited in Chapter II of this thesis are worth restating now. The first, from Wendt (1992, p. 70), recognised that national territories exist only in context of mutual recognition of those territories. The second, from Wilson and Donnan (1998, p. 9), is that this recognition serves to signify the 'the eminent domain of that state'. For China, added to this can be the nature of the identity for which recognition is being pursued; as multi-faceted, intricately linked to conceptions of China's past and contemporary greatness, morality, ascendency from humiliation, and national unification.

It should not, therefore, surprise us that China can be seen to use its territorial disputes to gain recognition of its perceived self from its neighbours. States' borders, and by extension their understanding of themselves relative to those borders, are 'constituted by the ongoing enactment of a broad set of social interactions between states' (Carlson, 2010, p. 680). When China's conceptions of itself have come under threat, this thesis has shown that efforts to realign identity and behaviour have occurred through the recognition of these identities at China's territorial limits. Where borders have acted as the limit of China's sovereignty of a nationally pluralistic State, interactions at these borders have sought to reemphasise this sovereignty. It is for this reason that China did little to pursue settlement in the early years of the PRC, while Chinese ontological security was focussed on the international community. Nevertheless following transformations to China's identity, the ensuing pursuit of ontological security was manifest in China's cooperative behaviour at its borders. This can be seen in the early 1960s, in which the pursuit of a China united in class struggle saw China settle (or attempt to settle) with Indian, Burma, and various other nations. In the early 1990s, Chinese cooperation in the Sino-India dispute occurred at a time when China was seeking loyalty to the State through the association of Chinese identity and nationalism with all those within the State's territorial limits. Equally, Chinese perceptions of a more direct external threat to this ontology have resulted in conflict in order to remove such a threat and re-establish routine in 
China's interactions with the disputant state, as occurred with India in 1962. Alternatively, where territory disputes have extended beyond the realms of China's population and into the areas contested by states traditionally seen as subordinate quasi-vassals of China, China's behaviour has acted to reinforce perceptions of itself as a superior state. This can occur through both the aggressive coercion of smaller states, as occurred when ontological threats arose from interactions with disputant states which were dismissive of China's identity as the central and superior Asian state. Equally, cooperation in these disputes, as at the turn of the century, occurred when China's Self took on the historical role of a superior central state which is uniquely harmonious and peaceful.

Further research is required to ascertain the validity of this thesis to further Chinese territory disputes. Nonetheless, a brief reading of further disputes suggests that the validity of this approach is not confined to the case studies discussed above. For example, the Nepalese settlement of the Tibetan boundary in the early 1960s reflects the issues arising from the Indian dispute. In this case, China had chosen not to negotiate from the mid-1950s, only to change its course and welcome settlement through concession, with negotiations beginning in March 1960 (Hyer, 1990, p. 189), shortly after the ontological threat regarding Tibet had occurred. Equally, negotiations with the Soviet Union were first pursued by China in 1960, coinciding with efforts to secure Chinese national unity elsewhere. Chinese efforts to settle this dispute through concession redoubled following ethnic Kazakh migration and Soviet propaganda in Xinjiang in the northwest of the border, while in the northeast China's concession was offered subject to the inclusion of 64 Chinese villages within the Chinese border (Fravel, 2008, p. 101; Hyer, 1990, p. 283). Both these points suggest that the inclusion of border peoples within the Chinese nation was central to the Chinese position in this dispute. Alternatively, strengthening differences in ontological security in maritime disputes, the central importance of the Century of Humiliation to the ongoing Sino-Japanese dispute over the Senkaku islands, principally related to China's victimisation under Imperial Japan, is well acknowledged in existing literature (Wiegand, 2009).

Finally, this thesis has contributed to International Relations scholarship in several ways. Broadly speaking, it has extended the validity of the ontological security approach to territory disputes, an approach of relatively limited application to date. In doing so, this thesis has added to the growing body of International Relations literature in which the material security of a State is not seen as its primary motivation. It is in the same sense that this thesis has 
added to literature on China and its territory disputes. The prevalence of realist approaches to China's behaviour in its disputes has faced little opposition from alternative theoretical approaches, in the absence of liberal explanatory theories for this behaviour, and constructivist approaches which have generally focussed on interaction with a single external state. However, what this thesis has shown is that an analysis of Chinese national identity is integral to the proper understanding of Chinese behaviour across its many disputes. Furthermore, such analysis need not be limited to apparent irredentist pursuits of lost territory. Given common rhetoric which sees these disputes as primary points of international tension, it is an appreciation which both International Relations scholarship and international policy makers stand to benefit from. 


\section{Bibliography}

Agreement on the Maintenance of Peace and Tranquility along the Line of Actual Control in the India-China Border Areas. (1993). Retrieved February 15, 2015, from United Nations Peacemaker: http://peacemaker.un.org/sites/peacemaker.un.org/files/CN\%20IN_930907_Agreeme nt\%20on\%20India-China\%20Border\%20Areas.pdf

Amerkar, G. V., \& Diverkar, V. D. (Eds.). (1964). Documents on China's relations with South and South-East Asia (1949-1962). Bombay: Allied Publishers Private Ltd.

Bedi, R. (2014, October 1). India, China resolve border stand-off. IHS Jane's Defence Weekly, 51(40), p. 6.

Burchill, S. (2009). Liberalism. In S. Burchill, A. Linklater, R. Devetak, J. Donnelly, T. Nardin, M. Paterson, et al. (Eds.), Theories of International Relations (4th ed., pp. 5785). New York: Palgrave MacMillan.

Buszynski, L. (2003). ASEAN, the Declaration on Conduct, and the South China Sea. Contemporary Southeast Asia: A Journal of International and Strategic Affairs, 25(3), 343-362.

Callahan, W. A. (2004). National insecurities: Humiliation, salvation, and Chinese nationalism. Alternatives, 29(2), 199-218.

Callahan, W. A. (2009). China: The pessoptimistic nation. London: Oxford University Press.

Carlson, A. (2010). Constructing the dragon's scales: China's approach to territorial sovereignty and border relations in the 1980s and 1990s. Journal of Contemporary China, 12(37), 677-698.

Chen, J. (2001). Mao's China and the Cold War. [Kindle version]. Retrieved from http://www.amazon.com

Chinese government's position paper on matter of jurisdiction in South China Sea arbitration initiated by Philippines. (2014, December 7). Retrieved January 10, 2015, from People's Daily Online: http://en.people.cn/n/2014/1207/c90883-8819177.html 
Communication received with regard to the joint submission made by Malaysia and Viet Nam to the Commission on the Limits of the Continental Shelf: China. (2009). Retrieved from United Nations Division for Ocean Affairs and the Law of the Sea: http://www.un.org/depts/los/clcs_new/submissions_files/mysvnm33_09/chn_2009re_ mys_vnm_e.pdf

Curtis, H. (2014). Constructing Cooperation: Chinese Ontological Security Seeking in the South China Sea Dispute. (Unpublished manuscript), Victoria University of Wellington, Wellington.

Declaration on the Conduct of Parties in the South China Sea. (2002). Retrieved January 15, 2015, from Association of South East Asian Nations: http://www.asean.org/news/item/declaration-on-the-conduct-of-parties-in-the-southchina-sea

Department of State. (1964). Burma-China Boundary. International Boundary Study.

Donnelly, J. (2009). Realism. In S. Burchill, A. Linklater, R. Devetak, J. Donnelly, T. Nardin, M. Paterson, et al. (Eds.), Theories of International Relations (4th ed., pp. 31-85). New York: Palgrave MacMillan.

Downs, E. S., \& Saunders, P. C. (1998). Legitimacy and the limits of nationalism: China and the Diaoyu Islands. International Security, 23(3), 114-146.

Dreyer, J. T. (1976). China's forty million: Minority nationalities and national intergration in the People's Republic of China. Cambridge: Harvard University Press.

Elman, B. A. (2007). Ming-Qing border defence, the inward turn of Chinese cartography, and Qing expansion in Central Asia in the eighteenth century. In D. Lary (Ed.), The Chinese state at the borders (pp. 29-56). Vancouver: UBC Press.

Fravel, M. T. (2005). Regime insecurity and international cooperation: Explaining China's compromises in territorial disputes. International Security, 30(2), 46-83.

Fravel, M. T. (2007/2008). Power shifts and escalation: Explaining China's use of force in territorial disputes. International Security, 32(3), 44-83.

Fravel, M. T. (2008). Strong borders secure nation: Cooperation and conflict in China's territorial disputes. Princeton: Princeton University Press. 
Fravel, M. T. (2010). International Relations theory in China's rise: Assessing China's potential for territorial expansion. International Studies Review, 12, 505-532.

Gao, Z., \& Jia, B. B. (2013). The nine-dash line in the South China Sea: History, status, and implications. The American Journal of International Law, 107(1).

Garver, J. (2011). The unresolved Sino-Indian border dispute: An interpretation. China Report, 47(2), 99-113.

Garver, J. W. (1992). China's push through the South China Sea: The interaction of bureaucratic and national interests. The China Quarterly, 132, 999-1028.

Garver, J. W. (2004). India, China, the United States, Tibet, and the origins of the 1962 war. India Review, 3(2), 9-20.

Giersch, C. P. (1998). Qing China's reluctant subjects: Indigenous communities and empire along the Yunnan frontier. (Doctoral dissertation), Yale University, New Haven.

Ginsburgs, G., \& Pinkele, C. F. (1978). The Sino-Soviet territorial dispute, 1949-64. New York: Praeger Publishers.

Goh, S. N. (2012, December 10). China Yet to Grow into a leadership role. Retrieved from The Straits Times: http://www.straitstimes.com/the-big-story/asiareport/china/story/china-yet-grow-leadership-role-20121210

Goldsmith, B. E. (2007). A liberal peace in Asia? Journal of Peace Research, 44(1), 5-27.

Guang, L. (2006). From national indentity to national security: China's changing responses toward India in 1962 and 1968. The Pacific Review, 17(3), 399-422.

Gustafsson, K. (2014). Memory politics and ontological security in Sino-Japanese relations. Asian Studies Review, 38(1), 71-86.

Hara, K. (2012). The San Francisco Peace Treaty and frontier problems in the regional order: a sixty year perspective. The Asia - Pacific Journal, 10(1).

Hinton, H. C. (Ed.). (1980). The People's Republic of China 1949-1979: A documentary survey - 1957-1965: The Great Leap Forward and its aftermath (Vol. 2). Wilmington, Delaware: Scholarly Resources Inc. 
Hyer, E. (1990). The politics of China's boundary disputes and settlements. (Doctoral dissertation), Columbia University, New York.

Jiang, Z. (2012). Speech by president Jiang Zemin at George Bush presidential library. Retrieved from Ministry of Foreign Affairs of the People's Republic of China: http://www.fmprc.gov.cn/eng/topics/3719/3721/t19082.htm

Keep peace on China-India border: Official. (2009, December 2). Retrieved January 13, 2015, from People's Daily Online: http://en.people.cn/90001/90776/90883/6829558.html

Kratochwil. (1988). Regimes, interpretation and the 'science' of politics: A reappraisal. Journal of International Studies, 17(2), 263-284.

Kratochwil, F. (2006). Constructing a new orthodoxy? Wendt's social theory of international politics and the constructivist challenge. In S. Guzzini, \& A. Leander (Eds.), Constructivism and international relations: Alexander Wendt and his critics (pp. 2147). New York: Routledge.

Lamb, A. (1964). The China-India border: The origins of the disputed boundaries. London: Oxford University Press.

Lamb, A. (1968). Asian frontiers: Studies in a continuing problem. London: Pall Mall Press.

Lamb, A. (1973). The Sino-Indian border in Ladakh. Canberra: Australian National University Press.

Leibold, J. (2007). Reconfiguring Chinese nationalism: How the Qing frontier and its indigenes became Chinese. New York: Palgrave MacMillan.

Liu, X. (2011). Look beyond the Sino-Indian dispute. China Report, 47(2), 147-158.

Mackerras, C. (1994). China's minorities: Integration and modernization in the twentieth century. Hong Kong: Oxford University Press.

Maung, M. (1961). The Burma - China boundary settlement. Asian Survey, 1(1), 38-43.

Maxwell, N. (1970). India's China war. London: Jonathan Cape Limited. 
Maxwell, N. (1999). Sino-Indian border dispute reconsidered. Economic and Political Weekly, 34(15), 905-918.

Mearshimer, J. J. (2006, April). China's unpeaceful rise. Current History, 105(690), 160-162.

Mitzen, J. (2006). Ontological security in world politics: State identity and the security dilemma. European Journal of International Relations, 12(3), 341-370.

Nie, H. (2009). Explaining Chinese solutions to territorial disputes with neighbour states. Chinese Journal of International Relations, 2, 487-523.

Ogden, C. (2013). A normalised dragon: Constructing China's security identity. Pacific Focus, 28(2), 243-268.

Raine, S., \& Le Miere, C. (2013). Chapter one: Mapping the history. Adelphi Series, 53, 2954.

Reus-Smit, C. (2009). Constructivism. In S. Burchill, A. Linklater, R. Devetak, J. Donnelly, T. Nardin, M. Paterson, et al., Theories of International Relations (pp. 212-236). New York: Palgrave MacMillan.

Rozman, G. (2011). Chinese national identity and its implications for international relations in East Asia. Asia-Pacific Review, 84-97.

Smith Jr., W. W. (2009). China's Tibet? Autonomy or assimilation. Plymouth: Rowman \& Littlefield Publishers Inc.

Sperling, E. (2008). The politics of history and the Indo-Tibetan border. India Review, 223239.

Steele, B. J. (2008). Ontological security in international relations: self-identity and the IR state. Abingdon, Oxon: Routledge.

Sun, X., \& Huang, Y. (2012). Revisiting China's use of force in Asia: Dynamic, level and beyond. Pacific Focus, 27(3), 393-420.

Sutter, R. (2011). China-Southeast Asian relations: Managing rising tensions in the South China Sea. Comparative Connections, 13(2). 
Suzuki, S. (2014). The importance of 'Othering' in China's national identity: Sino-Japanese relations as a stage of identity conflicts. The Pacific Review, 20(1), 23-47.

Vietnam and China ships 'collide in South China Sea'. (2014, May 7). Retrieved January 10, 2015, from BBC: http://www.bbc.co.uk/news/world-asia-27293314

Watson, F. (1966). The frontiers of China. London: Chatto and Windus.

Wendt, A. (1992). Anarchy is what states make of it: The social construction of power politics. International Organization, 46(2), 391-425.

Wiegand, K. E. (2009). China's strategy in the Senkaku/Diaoyu Islands dispute: Issue linkage and coercise diplomacy. Asian Security, 5(2), 170-193.

Wilson, T. M., \& Donnan, H. (1998). Nation, state and identitiy at international borders. In T. M. Wilson, \& H. Donnan (Eds.), Border identities: Nation and state at international frontiers (pp. 1-30). Cambridge: Cambridge University Press.

Woodside, A. (2007). The centre and the borderlands in Chinese political theory. In D. Lary (Ed.), The Chinese state at the border (pp. 11-28). Vancouver: UBC Press.

Zhang, F. (2011). The rise of Chinese exceptionalism in international relations. European Journal of International Relations, 19(305), 305-328.

Zhao, H. (2013). The South China Sea dispute and China-ASEAN relations. Asian Affairs, 44(1), 27-43. 